\title{
Building a Multicultural Society by Political Integration
}

\subsection{INTRODUCTION}

Switzerland seems to be one of the most privileged countries in the world. Whereas its direct neighbours were engaged in the destructive conflicts of World Wars I and II, Switzerland survived as a successfully neutral and independent small nation in the heart of war-torn Europe. Today, its inhabitants enjoy one of the highest living standards among industrialised countries. The country lacks natural resources, but Swiss industries produce high-quality goods of global renown: from precision machines and watches through chocolate and cheese to pharmaceutical and chemical products. Its services such as banking, insurance and tourism are equally appreciated all over the world. With high import and export rates, Switzerland is strongly dependent on the European and world markets yet has maintained its ability to compete in many fields. Although Switzerland's population is small and the country landlocked, it can compete with the largest developed nations. In exported goods, Switzerland ranks 17th in the world and among foreign investors 8th (CIA World Factbook 2019). What was once a poor region of mountain farmers, mercenaries and emigrants has become the third-largest holder of foreign exchange and gold reserves. No wonder it is seen as a model case of successfully finding a profitable niche in world markets (Box 2.1 and Fig. 2.1).

Swiss residents pay relatively low taxes for the many benefits they receive from their government. There are high-quality, reliable public transport systems which not only link cities but also extend up to small mountain 


\section{Box 2.1 Characteristics of Switzerland}

\section{A. Geography}

Switzerland is a landlocked country at the heart of Western Europe. Its total surface spans $42,000 \mathrm{~km}^{2}$, divided into three main areas: the Jura mountain region in the North-West, the Alps in the South/South-East and the Mittelland plains spread out between the two. Less than $10 \%$ of its soil are residential/industrial, $36 \%$ are agricultural, 32\% forests, and the remaining 25\% unproductive. Switzerland borders five countries: Italy in the South, France in the West, Germany in the North and Liechtenstein and Austria in the East. Various lakes and rivers flowing in different directions (Rhine, Aare, Rhone, Ticino and Inn) complete the picture.

\section{B. Population}

By the end of 2019, some 8.6 million people had permanent residence in Switzerland. One in five inhabitants lives in one of the ten largest cities, but the average population size of the roughly 2000 municipalities is still only 3800 . The largest city is Zurich with 430,000 inhabitants. Twenty-five per cent of the Swiss population, that is, some 2.1 million persons, do not possess the Swiss nationality-although $19 \%$ of those (i.e. some 410,000 ) were born in Switzerland. In turn, some 750,000 Swiss live abroad. German, French, Italian and Romansh are all national languages, spoken by $63,23,8$ and $0.5 \%$ of inhabitants, respectively. Five per cent have English as their main language, $19 \%$ another language. ${ }^{1}$ In terms of religion, $36 \%$ of residents are Catholics, $24 \%$ Protestants, $6 \%$ practise another Christian faith, $5 \%$ are Muslims, $0.3 \%$ Jewish, $3 \%$ belong to another or an unknown religion and $26 \%$ have none. While language proportions have remained stable over centuries, Protestants have lost their majority (1910: 56\%) due to secularisation and immigration from Catholic countries such as Italy, Spain and Portugal.

(continued)

\footnotetext{
${ }^{1}$ Respondents could indicate more than one main language, which is why the total exceeds $100 \%$.
} 


\section{Box 2.1 (continued)}

\section{Economy}

In 2017, Switzerland's Gross Domestic Product (GDP) was 523 billion US Dollars. This corresponds to some 62,000 US Dollars per inhabitant, placing the country 16th worldwide, behind the various oil and fiscal paradises. Seventy-four per cent of GDP derive from services, $26 \%$ from industry and $0.7 \%$ from agriculture. Ninety per cent of companies have less than nine employees, but $32 \%$ of employees work in companies with 250 or more staff. Exports mainly go to Germany (15\%), the US (12\%) and China (8\%), imports mainly come from Germany (21\%), the US (8\%) and Italy (7\%). Unemployment rate is a low $3 \%$. Nevertheless, some $8 \%$ of the population live below the poverty line and a further $15 \%$ are at risk of poverty. Figure 2.1 shows how the share of non-Swiss residents and the expansion of the services-sector have both grown enormously since 1960.

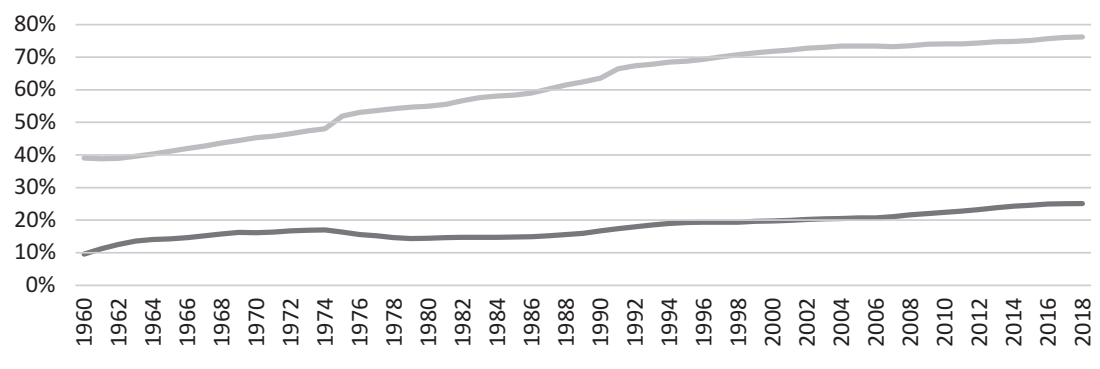

Fig. 2.1 Service economy and immigration, 1960-2018: two indicators of socio-economic change [\%]. (Sources: CIA World Factbook (2019); BFS (2019))

villages. The infrastructure for roads, energy supply and telecommunications is comprehensive and well maintained. Public education is of a high standard, especially in vocational training. In some research domains, the two Federal Institutes of Technology in Lausanne and Zurich are world 
leaders. Health and social services are available to everybody, even if the costs of both have steadily increased over the past decades.

Finally-and here we come to the heart of the matter-the political stability of Switzerland is outstanding. With only a short interruption, the seven-member Swiss government has been composed of the same four parties since 60 years. Together, they have represented between $70 \%$ and $90 \%$ of the Swiss electorate (BFS 2019). Despite the fact that every year the people vote on some six proposals to change the Constitution (average for 1999-2019; Swissvotes 2019), Switzerland is not a country of political revolution. Maintaining a constrictive interpretation of the principle of neutrality, Switzerland has played a lesser role on the stage of international politics than other neutral countries such as Sweden or Austria. In doing so, it has avoided many of the conflicts and complications in international affairs that could have been dangerous, perhaps even catastrophic, for a small nation.

Outsiders thus wonder not only about Swiss conservatism, but also about a seeming absence of serious social, economic or cultural conflict. But even if they are right to suspect a connection between political stability and economic success, the question is how such stability arose in the first place.

In the context of Swiss history, this outcome is all the more puzzling since initial conditions seemed anything but favourable. It would also be fundamentally wrong to think of Switzerland as a country without historical conflicts. Modern Switzerland was not created by one homogeneous ethnic people, but by different groups speaking different languages and adhering to different religions. Nation-building was a slowly evolving, bottom-up process. Moreover, nation-building and the processes of urbanisation, industrialisation and modernisation were accompanied by societal conflicts just as in other countries. The latter are in many ways comparable to processes in developing countries today.

In 1848, the Swiss federation emerged out of a civil war between Conservative Catholics and progressive Protestants. Thereafter, despite its political neutrality, in World War I Switzerland almost fell apart because political elites opted for different sides in the conflict between its neighbours: the majority of German-speaking Swiss identified with Germany, while the French-speaking population sympathised with France (Jost 1986). Industrialisation was accompanied of rising economic inequality and a class struggle between workers and entrepreneurs. This culminated in a nationwide strike and the intervention of the armed forces in 1918. The workers, whose claims were all denied by the bourgeois government, radicalised their opposition politics in the following decade. 
An even bigger 'minority', namely women of Swiss nationality, had to wait until 1971 to be given the right to vote on national affairs. A first attempt had failed in 1959. Finally, after World War II an important ethnic conflict broke out in the canton of Bern, where a large part of the Frenchspeaking population in the Jura region felt ill at ease with the Germanspeaking majority. After a long political struggle, by 1979 they succeeded in creating a canton of their own, but the fate of one city, Moutier, remains undecided even in early 2020.

Today, the Swiss people are deeply divided on the question of European integration. Despite its geographical location in the heart of Europe, Switzerland is not a member of the EU, and in a 1992 referendum a majority even refused to join the European Economic Area (EEA). Switzerland thus faces the challenges of globalisation and Europeanisation on its own. Being a small state, it runs the risk that many of its traditional comparative economic advantages turn into disadvantages. Thus, the question of European integration remains controversial: 'Traditionalists' see Switzerland's best future in continuing its long-standing policy of neutrality and utmost sovereignty, while 'modernists' want Switzerland to become a member of the European Union or at least maintain close ties (e.g. Church 2016, ch. 11; Mazzoleni and Dardanelli 2019).

So how has the Swiss nation-state, once a Utopian idea, become a reality? How was Switzerland able to keep its independence as a political nation and deal with its many religious, economic, linguistic and class conflicts? And, finally: how was Switzerland able to transform itself into a modern, industrialised nation and develop a form of democracy that already in the nineteenth century went further than all other European countries?

In saying that Switzerland represents a 'paradigmatic case of political integration', we echo the view of Karl Deutsch (1976), a scholar looking at Switzerland from the outside. Indeed, the Swiss have become a nation with its own, distinct identity only through and because of its political institutions. Their role was fundamental in uniting territorial communities of four different languages, two different religions and many more different regional histories. What is more, political institutions were able to turn the disadvantages of cultural diversity such as fragmentation and conflict into advantages such as experimentation and solidarity. Key to this process was political integration and a particular way of dealing with conflicts and problems in a peaceful, democratic manner. In this chapter as well as in many other parts of the book, specific examples illustrate what integration meant and how it has worked to date. 


\subsection{The Origins of Modern Switzerland}

After the Vienna Congress in 1815, when much of the European prerevolutionary, old order was restored, nobody could have foreseen that Switzerland would shortly become one of the first modern democracies and a small nation-state.

The origins of Swiss integration can be traced back to three tiny alpine regions, which declared themselves independent from the Habsburg Empire in the thirteenth century. Other regions and cities then followed suit and by the time of the French Revolution, 13 regional polities (Orte, later named 'cantons') formed a loose confederation. However, what had once been a product of peasant resistance against outside jurisdiction and taxation had mutated into a feudalist regime of privileges, in which a fortunate few exploited the resources and people of newly acquired subject territories. This moribund ancien régime broke down when troops of the French Revolution, promising to bring liberty, equality and democracy, invaded Switzerland as they had other European countries.

While France was successful in breaking the privileges of the old cantons, it failed, not surprisingly, to merge the cantons into a united Helvetic Republic in 1798. Five years later, on the order of Napoleon Bonaparte himself, a part of the autonomy of the cantons was restored in the socalled Mediation Act, but in 1815-with Napoleon defeated-the Swiss chose to return to the old system. A loose confederation of now 25 independent cantons, which considered themselves sovereign states, was reestablished. The 'eternal' treaty guaranteed collective security by mutual assistance. A conference of canton delegates was empowered to implement common decisions. But delegates were bound by the instructions of their cantonal governments. Agreements and decisions were thus difficult to reach. The Swiss confederation of 1815 did not have a real parliament, let alone an executive body. In other words, Switzerland was not yet a true nation-state (e.g. Kästli 1998, 17-44; Vatter 2018b, 14ff.). ${ }^{2}$

In the decades after 1815 , the Swiss Confederation lived through a period of internal polarisation between two forces, the Conservatives and the Radicals. The Conservatives were Catholics from mainly rural regions in Central Switzerland, Fribourg and Valais. Being a minority, they insisted

\footnotetext{
${ }^{2}$ There is often confusion about the meaning of the term confederation. Here it is used to describe a treaty-based system of independent states, whereas the term 'federation' designates a state wherein power is shared between one central government and a number of non-centralised governments having the status of constituent or member states. Thus, Switzerland will be called a confederation for the period 1815-1848, and thereafter a federation.
} 
that decisions taken at the Conference of Delegates (Tagsatzung) should be unanimous. They were sceptical about the idea of strengthening the authority of the central government-just as the anti-federalist forces in the US had been a few decades before. In a time of early democratisation in the cantons, the Conservatives also wanted to preserve the traditional cultural and political role of the Catholic Church, especially regarding education. The Radicals, on the other hand, were rooted in mainly Protestant, industrialising cantons such as Zurich, Berne, Basel and Geneva. The Radicals strove foremost for democracy under the slogan of popular sovereignty, with the aim of public control of all authorities. The democratic revolutions in many cantons sought not only political rights for all people, the division of power, and publicity for the debates of the elected parliament, but also the separation of state and church. Radicals denied the Catholic minority the old social privileges of their church. From the sixteenth to the eighteenth century, the old confederation had suffered four internal religious wars-but it had also achieved agreements between Catholics and Protestants that led to periods of peaceful coexistence (Box 2.2). With the arrival of democracy, religious differences again led to conflict.

\section{Box 2.2 Religious Conflicts Between Protestant and Catholic Cantons, Sixteenth-Eighteenth Centuries}

1529: A military conflict between Protestant Zurich and the five Catholic cantons was prevented by the first Kappeler Landfriede which contained the promise of confessional tolerance.

1531: Battles between Catholic and Protestant troops from Zurich and Bern were won by the Catholics. The second Kappeler Landfriede was therefore in favour of the Catholics: Protestant confession was acknowledged but Catholics conserved some prerogatives. This second Kappeler Landfriede regulated the balance until 1656 .

1656: Zurich and Bern tried to improve their position vis-à-vis the Catholic cantons but lost the first battle of Villmergen, which confirmed Catholic dominance.

1712: The second battle of Villmergen was won by the Protestants. The victory eliminated Catholic hegemony in the Old Confederation and gave Protestant Zurich and Bern political influence appropriate to their growing economic power. 
Religion was not the only conflict between Radicals and Conservatives, but it became the focus for many other conflicts within and between the cantons. It led to rebellions and repression by military force, as when armed volunteers (Freikorps) of Radicals from other cantons wanted to 'liberate' Lucerne from its Catholic government. In 1845, the Catholic cantons signed a separate treaty (Sonderbund) to defend their common interests. They also demanded a revision of the confederal compact and tried to obtain diplomatic help (and more) from Austria, France and Sardinia. In 1847, the Catholic cantons left the Tagsatzung. This was interpreted by the Protestant cantons as secession. The differences over religion, culture and the political structure then escalated into a short civil war, which endedafter 26 days and with only about 100 casualties - with the defeat of the secessionists (Ernst et al. 1998; Remak 1993; Roca 2012).

The way was then free for the creation of a nation-state fundamentally different from that established by the confederative treaty of 1815. The victorious Radicals were the leading force in drafting a constitutional framework that involved:

- The bottom-up transition from a loose confederation to a federation: The 25 cantons (today 26) were willing to establish a national government and, upon becoming member states of the federation, to renounce on some of their sovereign powers;

- The creation of a multicultural state: According to the Constitution of 1848, the Federation consisted 'of the peoples (Völkerschaften) of the cantons'. In contrast to the unification of Germany or Italy, which happened in the same period, the concept of the state was thus not based on the same culture, religion or language of its people, but on the same citizenship of the different peoples of the cantons. Switzerland therefore represents a political or civic, not a cultural or ethnic nation;

- The transition to a constitutional democracy with an independent executive authority and its own parliament. Moreover, the Federal Constitution set minimum democratic standards for the institutions of the member states, including guarantees of certain political and civic rights, the separation of power, free elections to parliament and defining the cantonal electorate as the supreme authority for changing cantonal constitutions. 
The draft was submitted to a popular vote in 1848 . The votation did not conform to the same standard in all cantons because there was no common procedure. In Fribourg and Grisons, the cantonal parliament decided 'in the name of the people', whereas the Radical government of Lucerne interpreted the vote as a veto and thus added the $30 \%$ non-voters to the yes-side. Despite these irregularities, two thirds of the cantons accepted the project, and on 12 September 1848 the Tagsatzung declared that Switzerland's first ever Federal Constitution had been accepted by a large majority of people and cantons (Kölz 1992, 608ff.; Ruffieux 1983, 10f.; Ernst et al. 1998; Kley 2011).

Fully revised in 1874 and 1999 , the Constitution of 1848 nevertheless contained most of the organisational framework of today's polity (Boxes 2.3 and 2.4). Table 2.1 shows that the Swiss federal system consists of legislative, executive and judicial organs at each level. Note, however, that the Swiss system conforms less to the classical concept of separation of powers than to an idea of mutual cooperation and control that is partly comparable with the checks and balances of the US Constitution. Finally, Box 2.5 provides an overview of the Swiss party system.

\section{Box 2.3 Main Authorities of the Federation}

Federal Assembly: Bicameral parliamentary body representing the people (National Council) and the cantons (Council of States). Both chambers have equal powers. The Federal Assembly exercises the supreme authority of the federation, having the legislative power to make all federal laws, and appointing the members of the Federal Council and the Federal Court, the Commander-in-Chief or general (in times of war) and other major federal bodies. It supervises all authorities of the Swiss federal government and approves the annual budget proposed by the Federal Council.

Federal Council: Supreme executive and governing authority of the Swiss federation. Its composition mirrors power-sharing between different parties and cultures: the seven members of the Federal Council are representatives of four different political parties (in basically the same composition since 1959: three bourgeois centre-right and one left-wing party). An unwritten law 


\section{Box 2.3 (continued)}

requires that at least two members come from French- or Italianspeaking regions. The Council acts as a collegiate body. There is no role of prime minister with prerogatives over the other members of cabinet; thus, most decisions come from and are underwritten by the Council as a whole. One of the seven serves as president of the federation. By custom, this function is carried out by a different member each year. The president has no special political privileges, only formal duties. Each federal councillor heads one of the seven ministries (called departments): Foreign Affairs; Home Affairs; Justice and Police; Defence Civil Protection and Sports; Finance; Economic Affairs; Education and Research; and Environment, Transport, Energy and Communications. The federal administration, located mostly in Bern, has a staff of about 38,000 civil servants and employees - the army, national rail and postal services excluded.

Federal Tribunal: The Federal Supreme Court acts as the final court of appeal in cases coming from cantonal courts and involving federal law. Thus, the Court acts in all areas of Swiss law but in very different functions, depending on the specificity of the case. The Court also decides on conflicts between the federation and the cantons and on conflicts among the latter. It is empowered to review all legislative and executive acts of the cantons and guarantees the constitutional rights of the citizens. However, the Court does not have the power, either directly or by implication, to rule on the constitutionality of federal laws. The Supreme Court is located in Lausanne, with specialist chambers in Lucerne, St. Gall and Bellinzona. The Federal Assembly elects all judges for a term of office of six years. The composition of the Supreme Court complies with both cultural and partisan proportionality: all three state languages as well as the most important political parties are adequately represented. 


\section{Box 2.4 Direct Democracy}

Besides electing their parliament, the Swiss voters are provided with three important instruments of direct democracy: the popular initiative, the mandatory referendum and the facultative referendum.

The popular initiative is a formal proposition which demands a constitutional amendment. It must be submitted to the vote of the people and cantons if the proposition is signed by at least 100,000 citizens within 18 months. Before the vote, the Federal Council and the Federal Assembly give non-binding advice on whether the proposal should be accepted or rejected and occasionally formulate a counterproposal.

The mandatory referendum obliges parliament to submit every amendment of the Federal Constitution and important international treaties to the approval of a majority of cantons and the people.

The facultative referendum provides 50,000 citizens or eight cantons with the option to challenge any Act of Parliament within 100 days of its publication. If that quorum is reached, the Act is submitted to a binding vote, with a simple popular majority deciding on approval or rejection.

\subsection{Turning Poor Odds into Good Ones: Factors that Made Swiss Nation-Building a Success ${ }^{3}$}

As the short historical account of the previous section suggests, the transition from confederation to federation was not an easy one. First, the Conservatives' desire to maintain key elements of the old order made them fiercely opposed to giving away the sovereign rights of their cantons, preferring instead to maintain the status quo. The innovating forces, on the other hand, were firmly opposed to this. Second, there was the problem of cultural differences. Besides religion, there was the question of language. German was, and still is, spoken by some $70 \%$ of the population. Those in the French- and Italian-speaking regions feared that, as minorities, they would be made worse off by yielding their political power to a central government. Third, economic structures differed from canton to canton, as did preferences for trade regulations protecting the interests of farmers, craftsmen and traders.

${ }^{3}$ For general and comparative accounts of Swiss nationhood, see Eugster and Strijbis (2011) as well as Dardanelli and Stojanović (2011) and Zimmer (2003). 


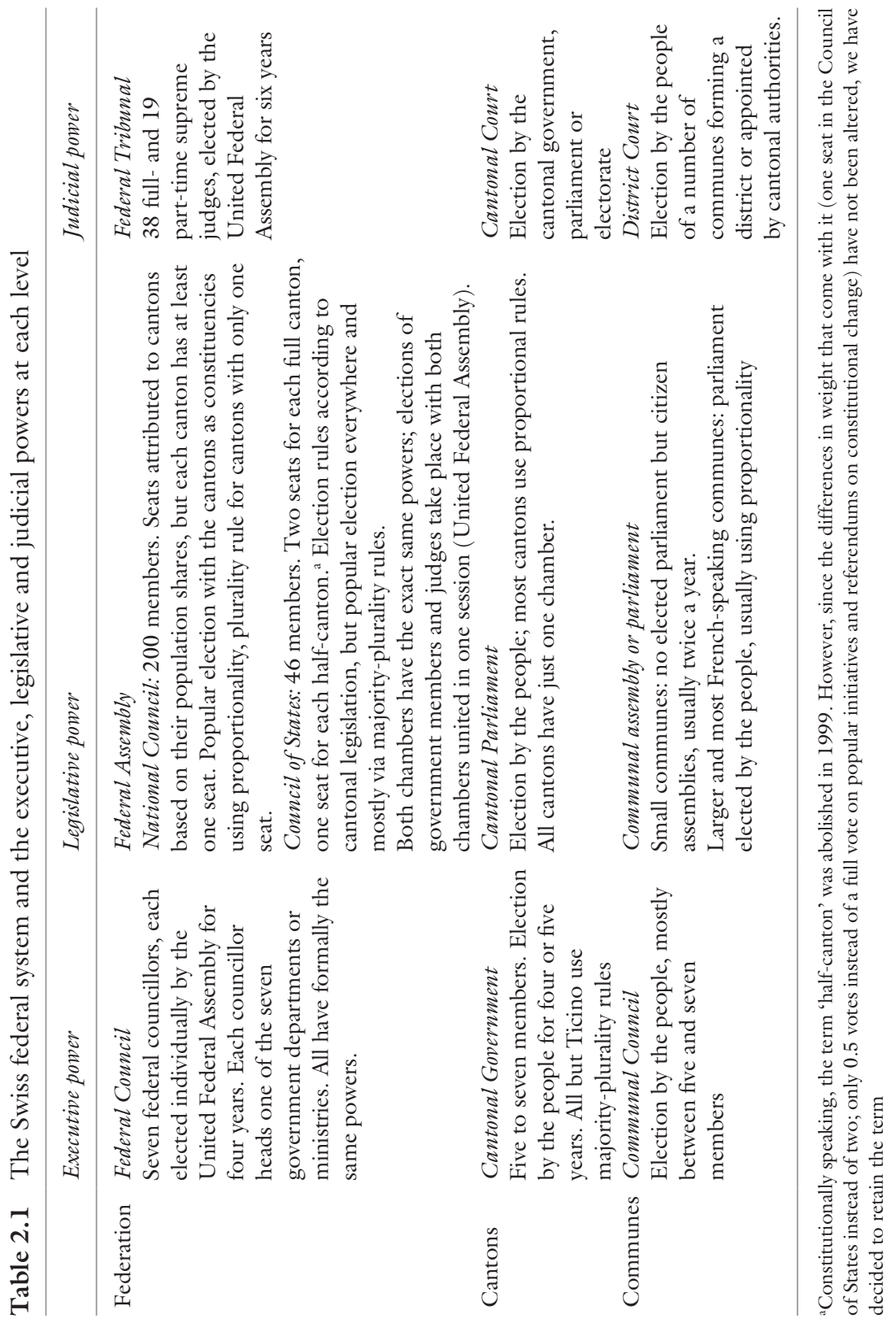




\section{Box 2.5 Political Parties}

The social cleavages and antagonistic political interests in the second half of the nineteenth century led to three main tendencies in Swiss political life: liberalism, conservatism and socialism. Coupled with the urban-rural and religious divide, these tendencies crystallised into the four governmental parties: Radicals (liberal, urban and largely Protestant), Christian-Democrats (conservative, rural and largely Catholic), Social-Democrats (socialist, urban and working class) and the Swiss People's Party (conservative, rural and historically Protestant). Federalism and proportional representation, however, have led to a highly fragmented multi-party system. Since there are no quotas, usually over ten different parties are represented in parliament.

A further distinction can be made between governmental and non-governmental parties. The development of political powersharing in the twentieth century has led to a multi-party government. From 1959 to 2003 , there was an informally fixed distribution of the seven executive seats among the four biggest parties (the 'magic formula') according to their electoral strength: two seats each for the Radicals, Christian-Democrats and Social Democrats, one for the Swiss People's Party (SVP). The rest of the parties occupied less than $20 \%$ of the electorate and did not form a coherent opposition. The SVP gained one seat in 2003 at the expense of the ChristianDemocrats, was out of government in 2008, but returned to occupy one and then two seats in 2009 and 2016, respectively. So the new formula is two seats each for the Radicals, SVP and Social-Democrats, one for the Christian-Democrats (see also Chap. 5).

The federal elections of 2019 led to substantial changes in the party system: All four governmental parties lost part of their supporters, whereas Greens and Green-Liberals almost doubled their electorate. The worldwide campaign against climate change thus did not fail to have a great impact on Swiss voters. The majority of the Federal Assembly, however, refused to allocate the Greens a seat in the Federal Council. Without the Greens and with two clearly overrepresented parties (Radicals and Social-Democrats), the arithmetic rule of proportional representation is violated. If the Greens can repeat their electoral success in 2023, adjustments of the 'magic formula' will have to be sought. 


\section{Box 2.5 (continued)}

The profiles of current governmental and non-governmental parties and their performance at the 2019 federal elections (National Council) are as follows:

\section{- Governmental parties}

- Radical-(Liberal) Democrats (15.1\% of the vote, 35\% female MPs): regards itself the heir to nineteenth century liberal ideas; enjoys close relations with business and industry and is highly influential in economic matters. Represents independent professionals, entrepreneurs and the upper-middle class.

- Christian-Democrats (11.4\%; 28\%): successor to the Catholic Conservative Movement. Still the preferred party of Catholics. With a bourgeois and a trade-union wing, it tries to integrate the opposing interests of entrepreneurs and employees.

- Social-Democrats $(16.8 \% ; 64 \%)$ : in former times periodically a Radical left movement. Today a moderate party standing for social, ecological and economic reforms. Enjoys close relations with trade unions. Most of its supporters live in urban, industrialised regions, but it draws on all social groups.

- Swiss People's Party (25.6\%; 25\%): once a conservative party appealing mainly to farmers, craftsmen and independent professionals, it has more than doubled its electoral force over the last 30 years and become the biggest political party. Defending Swiss sovereignty and neutrality, it is today situated at the national-conservative right. The success of the People's Party was the result of several factors: absorbing smaller right-wing parties, strong mobilisation of anti-European and anti-immigration parts of the electorate, populist strategies, stronger professional organisation, charismatic and authoritative party leadership and substantial financial resources.

- Non-governmental parties

- Greens (13.2; 61\%): party of the ecology movement; has drawn from left parties as well as from new social movements.

- Green-Liberals $(7.8 ; 50 \%)$ : split from the Green Party in 2007 to address centre-oriented ecologists, that is, voters 


\section{Box 2.5 (continued)}

willing to better protect the environment but without too much government regulation.

- Bourgeois-Democratic Party (2.4\%; 0\%): split from the Swiss People's Party in 2008, moderate right-wing party.

- Protestant Party $(2.1 \% ; 67 \%)$ : counterpart to the ChristianDemocrats, but without their electoral success.

- Alternative left $(1 \% ; 50 \%)$ : successor of former Radical left parties (mainly the Communist Party and progressive organisations) that have almost disappeared. Non-dogmatic, socialist, feminist and ecological.

- Federal Democratic Union (1\%; 0\%): Radical-right, defends Christian values, Eurosceptic.

- Lega dei Ticinesi $(0.8 \% ; 0 \%)$ : regionalist-populist party in Canton Ticino, anti-immigration like the SVP but sometimes also left-oriented in welfare questions.

Fourth, nationalism, at the beginning, was a kind of abstract Utopia. What is called nationalism today in East-European countries, for instance, is an appeal to a common cultural heritage or ethnic group. In Switzerland, the reverse applied: the people of the cantons represented different languages, ethnic groups and religions and had to be convinced that they should form a common nation, which to them was artificial in every respect. Certainly the people of the cantons were known as 'the Swiss', but they really felt themselves to be from Zurich, Uri, Geneva or Ticino, with little in common with people of other cantons. Last but not least, some cantons had serious internal conflicts. In Basel, for instance, the city was unwilling to give up its political control over the surrounding regions. When a compromise failed to be reached, the city and countryside separated to form two independent half-cantons. ${ }^{4}$

\footnotetext{
${ }^{4}$ In 1830, the rural population around the city of Basel demanded proportional representation in the cantonal parliament, that is, a number of seats according to their demographic weight. After the city refused, a civil war broke out in which numerous people were wounded and killed. In 1833, the Swiss confederation approved the separation of Basel into two halfcantons, bringing the conflict to an end (e.g. Andrey 1983, 247ff.).
} 
Thus, it was not easy to push the idea of a nation-state when political perspectives and horizons were shrinking rather than widening in many cantons. Instead of 'coming together' (Stepan 1999) to form a single nation-state, the cantons could have been stuck with their internal quarrels and vanish from the map of Europe.

So what did bring Switzerland together?

\subsubsection{Economy}

By the middle of the nineteenth century, early industrialisation had reached many cantons. New elites, whose status was based on industrial wealth and capital rather lineage and privilege, entered the public arena. The harnessing of power from rivers led to a pattern of decentralised industry, reaching far up into the Alpine valleys. The first railroad between Baden and Zurich opened in 1847, and from then on it became evident that the boundaries of cantonal markets were obstacles to growing industrial activities. The Federal Constitution of 1848 promised not only to remove these obstacles, but also to create a new, common economic market. It banned cantonal toll barriers and empowered the federal government to issue a Swiss currency as well as to introduce a federal postal service. Moreover, the Constitution aimed to promote 'common wealth' (gemeinsame Woblfahrt), and it promised equal rights as well as freedom of residence in any canton to all those who became Swiss citizens. One historian went so far as to say that the economic necessity of creating a common market was more important than the political ideas of Swiss nationalism (Rappard 1912).

\subsubsection{Pressure from the Outside}

When the great powers, at the Vienna Congress of 1815 , restored the patterns of Old Europe, Metternich and the delegates of the other countries were not unhappy about a neutral zone between Austria, SardiniaPiedmont and France. The Swiss confederation thus gained further recognition of its political neutrality (Box 2.6), which the cantons had begun to observe as early as 1648. Between 1815 and 1848, however, the cantons learned that they were somewhat dependent on the good-or bad-will of their powerful neighbours. While the latter were far from thinking of annexing the cantons, this did not make them refrain from diplomatic intervention into Swiss affairs. This situation was exacerbated by some cantons seeking diplomatic help from outside, as did the members of the Sonderbund (see above). 


\section{Box 2.6 Neutrality: A Necessary Aid in Building up the} Swiss Nation

Political neutrality has long been a traditional cornerstone of Swiss foreign policy. After a disastrous defeat in the battle at Marignano (near Milano) in 1515, the Swiss cantons slowly grew aware of the advantages of neutrality. In fact, this turned out to be the only way to maintain the integrity and independence of a confederation consisting of small cantons surrounded by larger and belligerent powers. Subsequently, the Swiss avoided becoming involved in conflicts between neighbouring states, especially during the 30 years of religious war in Europe which ended in 1648. It took a long time, however, for the unilateral declaration of neutrality to be recognised abroad. It thus did not prevent the Swiss cantons from being occupied by the French during the years 1798-1802. Things changed only after the Vienna Congress of 1815, when the European powers at last recognised the neutrality of the confederation, realising that it was in their own interest to use it to preserve the desired political equilibrium. After the creation of the federation in 1848, Switzerland became able to more efficiently defend its neutrality with its own armed forces. This was particularly important in the twentieth century, when Switzerland was one of the very few European nations not to be involved in either World War I or World War II (Riklin 2006).

Neutrality, historically, has had two main functions: internal integration and external independence. Integration through neutrality prevented the cantons of the old confederation from becoming divided by the conflicts of their neighbours and from being broken up into antagonistic religious and cultural camps. Later on, armed neutrality helped to preserve the independence of the Swiss federation. ${ }^{5}$

Today, the Swiss idea of neutrality is firmly based on the law of nations as formulated in the 'Hague treaty on the rights and duties of neutral powers and persons' of 1907. 'Neutrality in the sense of

(continued)

\footnotetext{
${ }^{5}$ Riklin (1991) adduces three additional functions: (a) the free trade function, (b) the function of maintaining a political equilibrium in Europe and (c) the function of offering 'good offices' in international relations. See also Kreis et al. (1992) and Goetschel (2007).
} 


\section{Box 2.6 (continued)}

the law of nations' means nothing more than the neutral nation's non-participation in a war involving other nations. In fulfilling this, first, Swiss neutrality is permanent and defended by an army. Second, Switzerland pursues a policy of doing everything to ensure neutrality in a future war. But Switzerland's policy goes far beyond this. After World War II, its extensive interpretation of 'neutrality' even meant non-participation in the European Community, the United Nations and other multilateral organisations. The reason given for this was the wish not to participate in economic sanctions or peace-enforcing measures, considered a threat to Switzerland's neutrality.

After the end of the Cold War, the government's policy has changed. In the 1990s, it participated in peace-keeping missions of the EU, the OSCE and the UN in the Balkans. In 2002, Switzerland decided by a popular vote to become a member of the UN. Neutrality is no longer an obstacle for participation in economic sanctions or peace-keeping operations, if decided by a universal organisation such as the UN (Kux 1994; Gabriel 1995; Gabriel and Fischer 2003).

In the middle of the nineteenth century, the cantons witnessed important experiments in nation-building as when the small neighbouring kingdoms of Sardinia-Piedmont, Lombardy-Venetia, Baden, Wurttemberg and Bavaria became parts of Italy and Germany, respectively. What would be the future of the small cantons when their neighbours developed as members of larger and more powerful nation-states - each of them speaking one of the Swiss languages? In fact, the process of Swiss unification developed a strong momentum by assuring a better collective security for all the cantons, and precisely the lack of linguistic unity forced the elite to seek other means of imaginary togetherness (Zimmer 2003). Thus, the Swiss Constitution of 1848 speaks of federal responsibilities to guarantee the independence of the Swiss nation in 'unity, force and honour', as well as to uphold internal security and order.

\subsubsection{Democracy and Social Values}

Enthusiastic nineteenth century writers praised the Swiss for their innate taste for democracy'. The Swiss were certainly not the inventors of 
democracy - such ideas were brought to Switzerland through the French Revolution-and while finding their modern form of democratic government, Swiss and US constitutionalists were mutually influenced. ${ }^{6}$ However, Switzerland did possess a cultural heritage which had prepared its people both to learn about democracy and to live with it: the Landsgemeinden (Meuwly 2018, 43). Also, the Swiss cantons had long been independent of both imperial and monarchical rule. While their old regimes were highly elitist, they were at least autochthonous (and, in French, 'plus paternalistes qu'autoritaires'; ibid., 24).

As small societies, the cantons were unable to develop complex regimes. Most lacked the resources to build up professional bureaucracies and to back the modern form of 'rational power' of the state. Especially in rural regions, public works - such as building roads or aqueducts in the Valais canton-were done on a community basis: every adult man was obliged to work for several days or weeks a year for the common good (Niederer 1965). In addition, many economic activities-farming in rural regions and crafts in the cities-were bound up in organisations which required collective decision-making. This, and the mutual dependence of people in small societies, promoted communalism. That was also reflected in the slogans used in the democratic revolutions in the cantons during the nineteenth century, when calls for the 'sovereignty of the people' became louder and louder (e.g. Meuwly 2018, ch. 5).

It is difficult to say whether Swiss democratisation came primarily from 'above' or 'below'. Certainly the democratic revolutions, which began in 1831 and swept through many cantons, involved more than just the elites. In the small canton of Thurgau, which then had less than 80,000 inhabitants, more than 100 petitions with 3000 propositions for a new democratic constitution were collected and discussed in the communes (Soland 1980). Some scholars, however, affirm that democratisation did not eliminate the elites then in power, but simply redistributed the cards for a new game under the same rules. Democratic revolutions neither took away the inherited wealth from old patrician families, nor did they prevent the concentration of capital in the hands of a few (Masnata and Rubattel 1991).

\footnotetext{
${ }^{6}$ According to James H. Huston (1991), there were several periods of mutual influence. Especially important were three periods: (a) in the debate between American federalists and anti-federalists, the latter took the model of the old Swiss confederation as their reference; (b) the Swiss, in 1848, had the American Constitution very much in their minds when combining the principles of federalism and democracy; (c) towards the end of the nineteenth century, the institutions of Swiss direct democracy were taken as a point of reference.
} 
Moreover, the rules of nineteenth century Swiss democracy were-by the standards of today-less than perfect: women were denied political rights, while some cantons established electoral rules that excluded poor or unmarried men from voting. Citizens elected their parliament but were denied the right to elect their government. Yet at the same time, political rights were gradually extended to allow the people a say over actual decisions of their parliament. This was the beginning of semi-direct democracy, which will be described in Chap. 4.

After 1831, the concept of democracy-implying equal voting rightsspread among all cantons and their different cultures. When it succeeded at cantonal level, the experience of democracy helped the process of unification: the sovereignty of the people was one of the few things that almost all the different cantons had in common, and what they wanted and agreed upon (see Box 2.7).

\section{Box 2.7 Developing a Collective Identity}

Successful nation-building needs cultural cement: the development of collective identity. Unlike nations such as France, Germany or Italy, Switzerland could not rely on one common culture, language or ethnicity, which were the prevailing bases of European nationbuilding in the nineteenth century. Therefore, it may have been difficult to find a common thread to bind together people from different cantons and thus identify themselves as 'Swiss'. However, the development of patterns of collective identity relied on 'civic' elements such as national symbols, shared history, common myths and finally the new federal polity.

After 1848, one can observe a search for a shared identity, for a common denominator (Im Hof 1991). Historians offered an integrating view of the past. The many local battles in the old peasant cantons to defend their independence against invasions by the 'Habsburg hordes' became part of a glorious heritage that all Swiss could be proud of. Historians also told that the Swiss elites went back as far as 1291, when three local leaders swore an oath of political independence and mutual help. This act of will was especially emphasised and declared to have been the birth of Switzerland.

On 1 August 1891, the oath of 1291 was for the first time celebrated on a national basis. History was personalised so as to improve 


\section{Box 2.7 (continued)}

the opportunity for identification. Legendary and symbolic figures such as William Tell (a hero killing a foreign tyrant) and Helvetia (the mother of the nation) were omnipresent on postal stamps, popular pictures and hundreds of pub and inn signs. Today, historians give a much more sober account of Swiss history when trying to distinguish between the facts and the myths. Some claim that William Tell never existed, and that the events in 1291 are fiction. Even if that were true, from the point of national identification, this misses the point: symbolic figures and myths gave life to the idea of a common Swiss culture, and probably more so than actual events because they were independent of a particular social structure and allowed people with different backgrounds to identify with them.

The Alps were another element of national identification. The picture of a nation consisting mainly of farmers and shepherds living in isolated mountain chalets or small villages was drawn to distinguish Switzerland from other countries, although large parts of Switzerland had already been industrialised by the nineteenth century.

From the very beginning, therefore, Swiss identity relied not only on what its people shared with each other, but also on very Swiss specificities (Ruckstuhl 1991, 136; Demont-Heinrich 2005)— things that allowed the Swiss to feel different from their neighbours. Most important in this respect was the Swiss polity itself. Swiss direct democracy is different from other types of democracy, and it has also become the most precious element of its common culture. Moreover, the fact that all men are legally bound to serve in the army is not only a means of social integration. Until 1971, when voting was the privilege of male citizens only, the duty of serving in the army was considered to be correlative with having political rights-and was used as an argument against women's suffrage. The ideology of all male citizens defending their country, and identifying with this task, was said to be the 'cement' of Swiss society especially during World War II.

Today, many of these symbols, myths and glorifications of history have lost their persuasiveness. But politically Swiss citizens are still convinced that their direct democracy is unique, their federalism and the neutrality of the country useful. The Swiss are proud if their football team wins an important game and sway the national flag as do the citizens of all other countries. 


\subsubsection{Combining Democracy with Federalism}

Democracy is founded on the principle of 'one person, one vote' and on the rule of the majority, which together make collective decisions binding for all. But is it defensible that a sizeable minority with different opinions and interests should have to comply with the decisions of the majority? One of the answers to this controversial question of political theory is that no majority decision is final. The minority should always have the right to propose a reconsideration of the decision taken, and if its arguments are convincing a new majority will be found for a revised decision. But while this may hold good for different opinions on common interests, it would not satisfy minority groups with religious beliefs or cultural values inherently different from those of the majority. French-speakers cannot become German-speakers and Catholics do not become Protestants because of democracy. If a society is deeply divided by such cultural or religious cleavages, democracy alone cannot help the problem of 'frozen' or 'eternal' minority or majority positions: the minority, which under pure 'one citizen, one vote' rules can never win, is likely to be frustrated and discriminated against. In turn, even for the eternal majority, who can afford not to learn, power can become pathological (Deutsch 1967, 214-43).

This was the exact problem when the Swiss cantons were ready to set up their central government. For good reasons, Catholic and non-Germanspeaking citizens and their cantons were fearful of being systematically overruled on questions of faith, language and culture more generally. Thus, if the popular desire for government by the people gave momentum to unification, democracy was at the same time disadvantageous to the prospects of the creation of a Swiss nation-state since it risked working only for some of them: the German-speaking Protestant majority.

Combining democracy with federalism provided the answer. Federalism allowed the sharing of power between one central government and the cantons. In all matters that were the responsibility of the cantons, different answers to the same question were possible-answers that corresponded to the preferences of different ethnic or religious groups, who although a minority nationally were majorities regionally. Thus, federalism permitted-and still permits-cultural differences to coexist alongside each other, and it protects minorities without infringing too much on the majority. As we shall see when discussing federalism in Chap. 3, the initial division of power between the federation and the cantons was very much in favour of the latter, providing for the utmost autonomy of cantons and 
their cultural, social and political particularities. In 1848, this division of power in favour of the cantons also meant a concession to the Catholic conservative minority, military losers of the civil war, which gave the statebuilding project a better chance of succeeding in the forthcoming referendum on the new Constitution.

Next to regional autonomy or self-rule, federalism also allowed the cantons to become active participants in central government decision-making (shared rule). The Constitution provided for a system of parliamentary bicameralism similar to that of the US. Thus, the National Council represents the Swiss people but is complemented by the Council of States, where all cantons are equally represented regardless of their population size. Moreover, the cantons also matter when deciding on constitutional amendments, since the Swiss-wide popular majority in favour has to be accompanied by a majority of cantonal electorates (double majority). In both instances, therefore, the democratic principle of 'one person, one vote' is combined with, on equal terms, the federal principle of 'one canton, one vote'. As we shall see in Chap. 3, this requirement for a cantonal majority has become very important.

\subsection{Religious and Ethnic Minorities: From Coexistence to Pluralism}

The Constitution of 1848 provided an institutional framework able to give unity to a diverse nation. It promised to peacefully resolve conflicts between minorities and majorities. A constitution, however, is only a legal document at first. Later it becomes a framework for political life, even if not political life itself. In this section, we turn from the framework to the picture and ask: how did formal political unity spur political integration and further develop the identity of Swiss society? Instead of treating this subject in a general form, we concentrate on the two minorities which were most important at the time, and for whom the success or failure of integration was crucial: Catholics and linguistic minorities.

\subsubsection{Political Catholicism: From Segmentation to Integration}

In the middle of the nineteenth century, the Catholic minority comprised about $40 \%$ of the Swiss population. The cantons more or less represented religiously uniform entities. In 1860, ten cantons had over $75 \%$ Protestants, 
eleven rather smaller cantons had over 75\% Catholics. Only four cantons (Geneva, Grisons, Aargau and St. Gall) had a more even distribution of religions. Despite the fact that Catholic-Conservatives eventually achieved a good constitutional compromise, history first led to the segregation of the Catholic minority rather than to their integration. Politically, they retired to the strongholds of 'their' cantons and let the Radical majority take the initiative in forging the national unity of the new federal state.

Catholic regions were mostly rural, cut off from the industrialisation that was the main concern of the political elites in their progressive Protestant counterparts. The First Vatican Council of the Catholic Church, held in Rome in 1871, was hostile to the modernisation of society and scientific progress, opposed the separation of religion and state, and tried to enforce the position of the Pope as the sole and binding authority in all aspects of life. Both factors led to isolation and segregation. Many Catholic cantons entrusted the Catholic Church with the task of public education or maintained segregated public primary and secondary schools. Even in a few mixed cantons, religious segregation in schools was continued well into the second half of the twentieth century. In Fribourg, a Catholic university was founded in 1889. A tight web of social organisations kept Catholics together and close to the church-both in their home cantons and in the diaspora regions where Catholics constituted a minority.

Catholics not only had their own political party, they also had their own trade unions, newspapers and bookshops. In mixed regions, they remained loyal to the Catholic butcher, pub, plumber and carpenter-even when the quality of a Protestant competitor was said to be better (Altermatt 1991, 147). This kind of segmentation also existed on the other side, but to a much lesser extent: Protestant Switzerland lacked both the political leadership of a confessional party and the moral pressure of a single church to integrate all social classes on a continuing basis.

No wonder that conflict over religious issues became acute, especially in the mixed cantons. Swiss history books speak of the 'cultural struggle' (Kulturkampf) because the issue went far beyond religion to embrace different views of the role and interplay of society and state. The first total revision of the Federal Constitution in 1873-1874 was influenced by this struggle, which reached its peak around 1870. The Constitution of 1874 aimed at a fully secularised state and eliminated most public functions of the church. Several articles of the Constitution confirmed the anti-clerical character of the federation and the isolation of Catholics. Examples are: 
- The prohibition of Jesuit activities;

- The prohibition on founding and restoring monasteries;

- No creation of episcopates without the permission of the federation;

- Federal control of citizenship and protection of marriage by the state;

- Ban of clerical courts and jurisdictions;

- The obligations for the cantons to establish confessionally neutral schools under the direction of the state; and

- Full religious freedom without privileging any of the Christian confessions.

Insofar as these provisions were discriminating against Catholics, they have been eliminated from the Constitution in the second half of the twentieth century. Today, the regulation of the relationship between the church and the state is the sole responsibility of the cantons. These relations vary from canton to canton. Usually there is no complete separation of state and church: the Protestant, Roman-Catholic and the small ChristCatholic Churches are acknowledged as public institutions, called Landeskirchen. Some cantons-for instance Zurich-have given a similar status to the Jewish communities, but not to the 20 times larger Muslim communities which have grown rapidly in the last few decades.

The historic cultural conflict between Catholics and Protestants has by now faded away. Many of the issues were settled by the establishment of a modern, liberal democracy, which reduced the direct influence of religious organisations on the state. However, the more than four generations during which federalism permitted 'in-between' solutions to these conflicts needs to be noted. Thus, cultural issues were less 'settled' than given time to cool down.

This cooling down and the decline of the confessional schism was helped by several factors. First, the separation of Catholic and Protestant societies was overcome by modernisation. Geographically, a strong and steady migration between Catholic and Protestant regions opened 'ghettooriented minds' to religious tolerance and cooperation. Migration led to desegregation, which in turn helped integration. The declining influence of religion on people's lives opened the way to pragmatic solutions: smaller communities, instead of building two churches, constructed one that was used and maintained by both Catholics and Protestants. Marriage between Protestants and Catholics became common. Industrialisation and the modern economy did not distinguish between Catholic and Protestant money. Divisions disappeared as more and more Catholics gained equal access to those economic and social activities which had once been seen as 
typically Protestant. Cultural and political Catholicism itself developed pluralist attitudes towards the state. At the beginning of the 1970s, the former Catholic Conservative Party accordingly renamed itself the Christian-Democratic Party. The new label suggested the promotion of more general values of Christian belief and culture and acceptance of the separation of state and religion. This was similar to the programmes of Christian-Democrats in Germany and Italy after the end of World War II.

This brings us to the second, more political factor. Federalism permitted Catholics to maintain the particularities of their culture in their 'own' cantons during the first decades of the nation-state. Later the devices of direct democracy permitted the Catholic minority to participate, with considerable success, in federal decision-making. Notably after the introduction of the facultative referendum in 1874, Catholic-Conservatives were able to successfully challenge proposals by the Radical-dominated parliament. Simple majority politics therefore became impossible-the Catholics had to be integrated through participation in the government. Moreover, in 1918 a coalition of Catholic-Conservatives and SocialDemocrats succeeded in imposing proportionality rules for elections to the National Council. This meant the end of the absolute majority of the Radicals in the Swiss parliament, and for Catholics the beginning of powersharing. Most astonishing: with class struggles growing in importance, the Catholic opponent of the nineteenth century even became the closest ally of the Radicals in the twentieth century!

Beyond participation in the Federal Council and key positions in the federal administration, power-sharing meant compromises on legislative issues between Radicals and Catholic-Conservatives. It thus brought political influence, recognition and success to the Catholic part of society-and that success is enduring. Although religious cleavages have largely disappeared, Christian-Democrats still constitute one of the four governmental parties. Economically, they have become advocates of business interests almost as much as their Radical partners in government, although they often defend social policies together with the left. ChristianDemocrats, therefore, have become a pragmatic centrist party. Nevertheless, it should be noted that some crucial questions of the cultural schismsuch as the prohibition of Jesuits, who in the nineteenth century were regarded by Protestants as advocates and conspiratorial actors of counterreformation-were only resolved long after the practical relevance of the issue had disappeared. Questions regarding fundamental values and religious belief take time to be settled-or even a long period of voluntary non-decisions, thereby avoiding the re-awakening of old cultural conflicts. 


\subsubsection{Multilingualism: Understandings and Misunderstandings}

Multilingualism constitutes a second instance of the historical integration of cultural minorities into Swiss society (McRae 1964; Windisch 1992; Du Bois 1999). Today, about $73 \%$ of Swiss citizens speak German, 21\% French, $4 \%$ Italian and $0.6 \%$ Romansh, a minor language largely descending from Latin and spoken in a few Alpine regions in south-eastern Switzerland. ${ }^{7}$ The issue of multilingualism, however, differs in two ways from the subject previously discussed. Multilingualism-with the important exception of the Jura problem, discussed below-never became as crucial as the question of religious minorities. And, as we shall see, societal segmentation by language played, and still plays, a different role.

Let us first consider the institutional arrangements that protect linguistic minorities. Federalism, first, permits Romansh-, Italian- and Frenchspeaking minorities to live their own culture within the boundaries of 'their' canton(s). Moreover, being a majority in their canton, they also have a political voice in the decision-making of the central government. The historical importance of this voice may be illustrated by the fact that until 1974, the members of the National Council were seated in linguistic blocs (BAR 2011, 2).

Second, there are statutory rights for linguistic minorities. Linguistic autonomy is guaranteed by the principle of 'territoriality': the cantons are not only authorised but even obliged to guarantee the traditional language(s) of their region. Hence, newcomers need to adjust to whatever language is spoken in a given territory, and no commune can be forced to change its official language. German, French, Italian and Romansh are all defined as national languages. ${ }^{8}$ Banknotes and the most important federal

${ }^{7}$ If the total population, including the $25 \%$ foreign nationals, is taken into consideration, the proportion of Italian-speakers increases, whereas the proportion of German-people decreases (see Box 2.1).

${ }^{8}$ In 1938, Romansh was added as the fourth national language of Switzerland. This was the result of a 1935 request by the executive of Canton Grisons, at the height of Italian fascism under Mussolini. The initiators understood the request 'primarily as an aid to Romansh in its uphill struggle for survival against the inroads of modem communications and tourism' (see McRae 1964, 9). With an amendment to the Constitution in 1996, Romansh also became official language for state authorities 'when communicating with persons who speak Romansh' (BV 1999, Art. 70.1). 
Table 2.2 Proportional representation of linguistic groups

\begin{tabular}{lccrl}
\hline & German & French & Italian & Romansh \\
\hline Swiss population (5.3 million) & $72.1 \%$ & $23.7 \%$ & $6.2 \%$ & $0.7 \%$ \\
Federal Council (7 members) & $57.1 \%$ & $28.6 \%$ & $14.3 \%$ & $0 \%$ \\
National Council (200 members) & $73.0 \%$ & $23.0 \%$ & $4.0 \%$ & $0.5 \%$ \\
Council of States (46 members) & $73.9 \%$ & $21.7 \%$ & $4.3 \%$ & $0 \%$ \\
Federal Supreme Court (38 members) & $60.5 \%$ & $31.6 \%$ & $7.9 \%$ & $0 \%$ \\
Expert committees (ca. 1900 members) & $65.1 \%$ & $25.5 \%$ & $8.6 \%$ & $0.8 \%$ \\
Federal Administration (ca. 38,000 employees & 35,000 full time equivalents): \\
-All personnel & $70.8 \%$ & $22.1 \%$ & $6.6 \%$ & $0.4 \%$ \\
-Top management & $70.3 \%$ & $24.0 \%$ & $5.7 \%$ & $0 \%$ \\
\hline
\end{tabular}

Sources: Own calculations based on Bundesamt für Statistik (BFS) (2019), Bundesrat (BR) (2016), Delegate for Plurilinguism (2019)

Note: Population data only for Swiss citizens who are 15 years and older (2017); data for the Federal Council and Parliament from August 2019; data for expert committees from 2016, data for the federal administration for 2018

government documents are worded in all four languages. Romansh is the main language of less than 50,000 inhabitants (BFS 2019). So, for practical reasons most legal texts are translated only into German, French and Italian.

Third, we find a strongly enforced proportional rule that leads to political quotas. An unwritten rule says that two of the seven members of the Federal Council should be of French- or Italian-speaking origin, and over time, this has been well observed (Giudici and Stojanovic 2016). In governmental expert and parliamentary committees, too, linguistic proportions are observed more than any other proportional rule. Complaints about 'German predominance'-more common among French- than Italian-speakers - are not well founded when looking at federal personnel statistics: at all levels of government, proportionality is observed to a high degree.

However, in contrast to many other countries, Swiss quota are not defined as hard legal rules. While some of them are written as general regulations in law, most are informal, that is they are obeyed as a political custom. This allows for flexibility under concrete circumstances. As can be seen from Table 2.2, general regulations and informal quota can have astonishing results for the fair representation of different cultural groups. This does not necessarily mean, however, that also proportional influence is guaranteed. Take for example the Federal Council with seven members, 
of which currently two are French-speakers and one Italian-speaker. Here the proportional rule is well observed, even in favour of the minorities. However, the four German-speakers could easily overrule the others without even talking or listening to the French- and Italian-speakers. Moreover, the latter might be forced to learn German in order to understand what discussions are all about. Of course, minority representatives have the formal right to speak their language, but knowing that majority members might not understand them well it would probably be better to present a key argument in German. French- and Italian-speakers may also face a situation where the German-speaking majority, at the end of the formal session, begins to converse in their regional dialect(s): very different from standard or 'high' German and therefore barely understandable by Frenchand Italian-speakers. This worst case stands in sharp contrast to the best case, as when a polite German-speaking majority loves to speak French and makes French the official language of the discussions. Both of these cases happen in practice.

At the federal level, discussions in the National Council are simultaneously translated into all three (full) official languages. However, while the official record of Swiss laws and regulations is published in Italian, French and German, it happens that the documentation for parliamentarians is available only in one or two languages. The same is true of many government reports. Canada, for instance, goes much further, requiring every official document to be published in both English and French-probably because Canada has a more serious problem with its linguistic minority.

The Swiss are very conscious of the need for multilingualism: in schools, children are instructed in at least two languages. It is a myth, however, that these efforts lead to widespread bi- or trilingualism (Werlen 2008, $211 f$.). Most people rarely read newspapers or listen to news in a language other than their own, which means that they perceive politics by different media systems in the three linguistic regions. When face to face with a person speaking another language, it is normal, however, to try to communicate. Traditionally, German-speakers try to speak French to a Romand, even if their French is poor. Today young people, all of whom are taught English at school, are more and more using English as the lingua franca among themselves.

Multilinguism seems to offer advantages in internationalised business, too. The Swiss are actually rather proud of the multilingual aspect of their society and would find the question of whether German-, Italian-, Frenchor Romansh-speakers are 'better' Swiss people rather silly (cf. also Schmid 
2001). Multilingualism requires public expenditure and fiscal redistribution in favour of minorities, both of which the Swiss have been willing to bear. There are four complete public radio and television networks, one for each linguistic group. The networks of the linguistic minorities get a morethan-proportional share of the national budget. For instance, in 2018 Radio Télévision Suisse, generating 23\% of revenues, got 33\% (SRG 2019, 41).

These notions about language can be extended to cultural life in general. Cultural specificities exist also in lifestyle (Windisch 1992). There is a popular saying that German-speakers live to work, whereas French- and Italian-speakers work to live. These and other differences are an enriching element of Swiss life. They may sometimes create difficulties in communicating, but they are accepted as part of normal life. Thus, cultural and linguistic segmentation has not disappeared, unlike differences of religion as we saw above. Linguistic diversity has been kept-or rather reproduced-within the protecting boundaries of the cantons and linguistic communities. Differences appear also in political behaviour, for instance with respect to federal votations. French-speakers favour a more open foreign policy, while on issues concerning the armed forces, they are more sceptical than German-speakers.

With one exception (the Jura case discussed below), cultural segmentation has not been a major political problem for Swiss society as a whole. The virtues of pluralism may lie partly in the fact that the different cultures are separated from each other by the political autonomy of their cantons. It may be true that globalisation makes many societal differences between the cantons diminish or even disappear, while those with some groups of foreigners become more salient. But still, federalism provides a kind of horizontal segmentation which allows the three main regions of German-, French- and Italian-speakers to live apart without bothering each other too much (Watts 1991; Schmid 2001; Windisch 1992).

\subsubsection{Jura: The Exception to Integration}

Compared to the many multicultural societies which struggle with their cleavages, one could ask why Swiss society has integrated so successfully. We have no reasons to believe that the Swiss are more peaceful by nature than other people, nor their elites brighter than elsewhere. However, comparative politics literature suggests that there are institutional factors which generally favour processes of multicultural integration, such as a 
non-ethnic concept of the state, federalism, proportional representation and other mechanisms of political power-sharing. Pressure from the outside also helps fostering national unity provided it does not lead to armed intervention by a foreign power. All these factors were present in the Swiss case, and we shall come back to this in the conclusions to this chapter. Here, let us focus on one particular condition which can be decisive for the success or failure of political integration: cross-cuttingness.

Cleavages related to religion, language and the economy can be territorially overlapping or cross-cutting. When cleavages overlap, it means that a linguistic minority is also a religious minority and belongs to the poorer social strata of a society. If cleavages are cross-cutting, minorities are split into different groups. For instance, one part of the linguistic minority belongs to the religious majority, while another belongs to the religious minority. From a theoretical point of view, it is evident that in this case integration has better chances: a linguistic minority feels less discriminated against and may even be rewarded by integration if it is part of the religious majority. In situations of overlapping cleavages, however, the same group may suffer from multiple discrimination, which creates a much higher potential for grievances and ultimately political conflict (see also Steiner 1990).

The Swiss case is generally characterised by cross-cutting cleavages. Among French-speakers, for example, there are both Catholic and Protestant cantons. Among economically poorer cantons, there are both German- and French-speaking cantons. Thus, religious, linguistic and socio-economic cleavages do not coincide with the geographical boundaries of the cantons-instead, they cut across each other. The cumulation of different issues into one political conflict with just two sides-for instance, poor Catholic French-speakers versus rich Protestant German-speakerscould never develop. In practice, political majorities differ and vary from issue to issue. Most Swiss cultural groups have experience with being part of both a minority and a majority. This has been very important for the development of a culture of tolerance and pluralism.

There is an important case in modern Swiss history, however, where integration has somewhat failed. It concerns the Jura region, once the northern part of Switzerland's second largest canton, Bern. In a struggle of over 40 years which included riots and violence, the Jura minority, who felt discriminated against by Bern, fought for separation from the old canton. The creation of the new canton in 1978 will be described in Chap. 3, but the case is worth mentioning here precisely because of the factors of 
integration discussed above. First, the Jura region contained a double minority: French-speakers practising Catholicism in a Protestant canton dominated by German-speakers (Fig. 2.2).

Moreover, there were socio-economic differences. The Jura region, located on the periphery of the canton along the border with France, claimed to be economically neglected. In the Jura region, therefore, we find the rare case of overlapping socio-economic, language and religious differences. This overlap, however, was not equal throughout the region. The southern part of Jura was economically better off and had a Protestant majority. Thus, the population of Jura itself was divided into pro- and antiseparatist movements. After a series of popular votations at different levels (see Sect. 3.3.5), the new canton of Jura was eventually created. But the southern districts had voted to stay with Bern and therefore the Jurassian people, because of its internal fragmentation, were not integrated into a single political unit.

Whereas the creation of Jura canton was widely praised as the solution that corresponded most to the principle of self-determination by the people concerned, some separatist groups claimed that the southern districts should be reunited with the Jura canton. In other words, the potential for ethnic conflict was not completely removed with the 1978 solution. Catholics and French-speakers in the southern districts still complain about being a minority, cut off from the political body to which they feel they belong. However, if the southern districts were to be integrated into Jura canton, there would be a new problem for the Protestant minority, which feels more akin to Bern. The lesson to be drawn is evident: the ideal of ethnic and political overlap, so common in many nationalist movements, is a pipe dream. In most cases, while it does eliminate some minority problems, it cannot be realised without the creation of new problems.

\subsection{The Challenges of Socio-economic Inequality}

\subsubsection{A Working Class Without a Homeland}

Compared to other European countries, the industrialisation of Switzerland took place early, but it was somewhat different. Instead of concentrating in urban areas, important industries such as watchmaking, textiles and embroidery thrived in rural areas. This decentralised industrialisation prevented the sudden concentration of a mass proletariat in the cities. But, as in every capitalist country, industrialisation led to growing inequalities and 

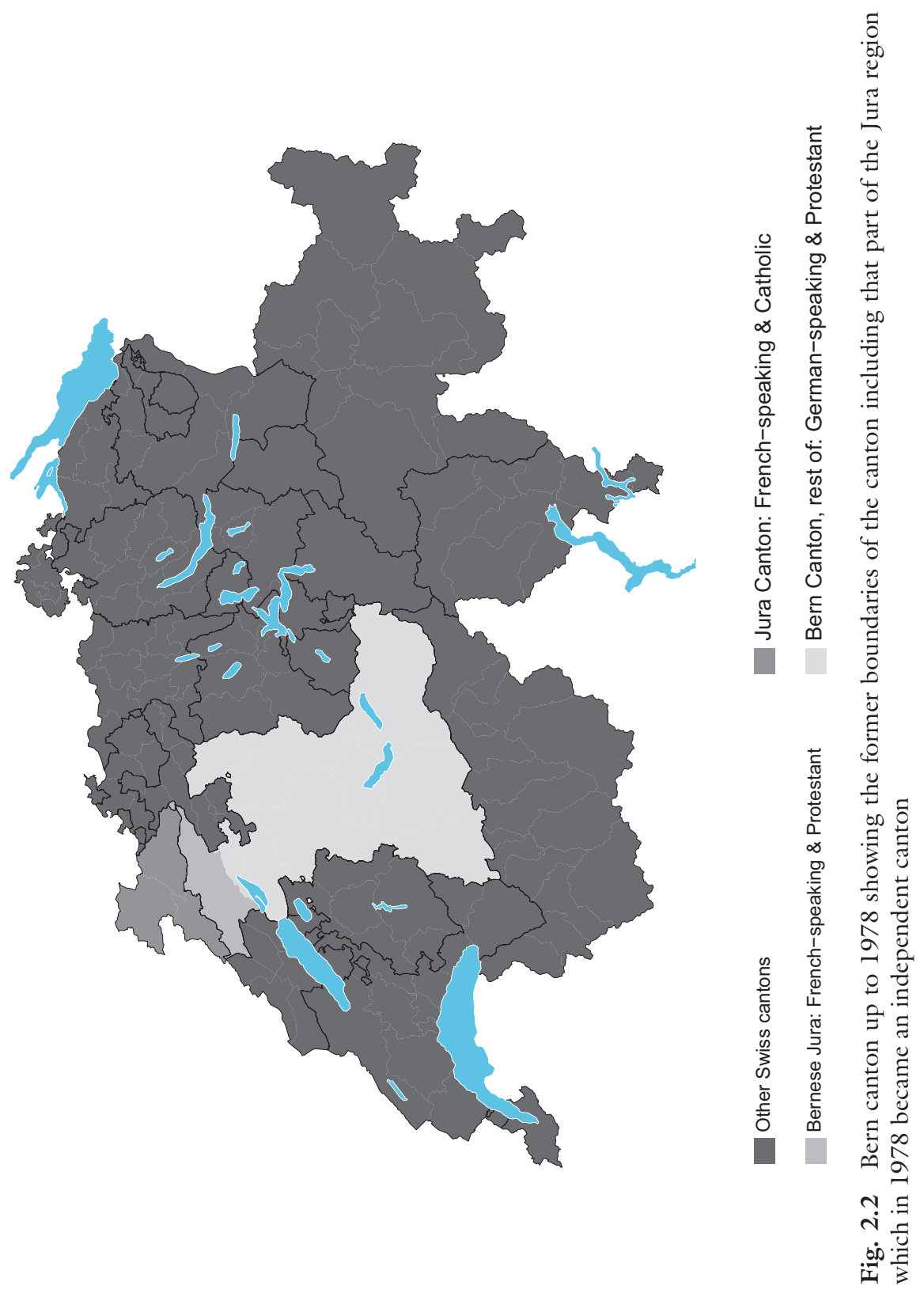
the impoverishment of a new social class of workers, whose jobs were insecure and whose earnings low. As in other countries, democracy prevented neither economic exploitation of workers nor inhuman working conditions (Gruner 1988). In the 1870s, the Radical politician Friedrich Bernet wrote: 'The Swiss Constitution of 1848 has put much political and economic power into the hands of a few. This has allowed the rich to grow richer, whereas other groups such as farmers, craftsmen and industrial workers are downgraded to an indistinguishable proletariat' (cit. in Gruner 1964).

At that time, neither a Socialist party nor a strong trade union for workers existed yet. Instead, it was a faction of the Radical Party which sought to defend the interests of the working class by a policy of "entrepreneursocialism'. They were concerned about growing social inequalities, which in their eyes were unacceptable in a democracy worth that name. The faction was the driving force behind the first regulations to protect workers and ban the use of child labour. This policy was strongly opposed by the liberal wing which, in the fashion of 'Manchester liberalism', wanted to avoid any government intervention into the free market. This marks the emergence of two new economic questions slowly superseding the older cultural schisms in Swiss politics:

- To what extent should the government protect Swiss industries against international competition and intervene in the free market?

- What role should be given to the government in compensating growing social inequalities created by market competition?

Unlike in other countries, such as Austria and Norway, business itself was divided on the question of the free market. Whereas some export industries pushed for unconditional liberalisation, farmers wanted to be protected from international competitors through levying duties on foreign products. Small trades and crafts enterprises were organised into corporations and also sought protectionist state regulations for things that were beyond their own capacity to deal with. The first vocational schools, for instance, were run by trades and crafts corporations, but the state provided subsidies and declared professional schools mandatory for apprentices. This eliminated the problem of free riders - enterprises that abstained from investing in professional training, but which would hire employees from other enterprises that had invested in them. 
Thus, from the very beginning Switzerland's economy tended to develop organised relations with the state. In a kind of highly fragmented corporatism, a great number of professional and business organisations cooperated with the state. They sought particular advantages through state regulations or subsidies, which eliminated the risks of free competition. In return, they offered to help in the implementation of government activities. Farmers' organisations, for instance, furnished the statistical data used in drafting agricultural policies, which helped to keep down the number of public administration staff. Despite their high praise of economic liberalism, and despite their tradition of anti-state ideology, organised professions and businesses have developed strong and influential relations with the national government which persist until today (Farago 1987; Church 2004, 71-81; Mach 2007).

In the race for the organisational build-up of economic interests, the workers were latecomers and did not organise until the end of the nineteenth century. They sure had a common interest to defend: the betterment of their economic conditions, promised also by the ideas of Socialism emerging in other European countries at that time. But in Switzerland, this common interest proved difficult to organise. Workers were spread all over the country and to a large degree isolated in smaller towns and villages. Here, the ties of traditional society and patterns of paternalism may have dampened the effects of economic inequality, but at the same time they hampered collective identity and the political organisation of the new working class. When the Social-Democratic Party was eventually founded in 1888 (Vatter 2018a, 107), it achieved rapid electoral success. SocialDemocrats and trade unions were also among the first to use the new instrument of the popular initiative at the federal level. In 1894, they demanded the right to work and a programme of public industrial policy-40 years before Keynes. But the hope that direct democracy would be the lever of social reform was dashed. In a popular vote that year, the proposed constitutional amendment was rejected by over $80 \%$ of voters and all cantons (BK 2019).

Later, cultural ties often proved stronger than economic cleavages. The Catholic Conservative party, its social organisations and unions successfully united Catholic workers. Thus, the working class was divided. While this did not prevent the Social-Democrats from becoming one of the largest parties, they never managed to form a coalition of equal strength to the bourgeois forces. Neither did the trade unions succeed in influencing industrial politics as much as businesses. This minority position of labour 
in politics and industrial relations has remained a Swiss characteristic (Farago 1987; Kriesi 1980). It differs from other small European countries, such as the Netherlands, Austria, Norway and Sweden, where more of an equilibrium between labour and capital, and between the political left and right, can be observed. Cultural segmentation and territorial decentralisation were key obstacles to the organisation of the left in Switzerland. Labour forces were never able to catch up with the organisational strength of businesses or even farmers.

\subsubsection{From Class Struggle to Economic Partnership}

In the first decades of the twentieth century, the conditions of the Swiss working class worsened. For the period before World War I, historians note the development of a conservative, nationalist, sometimes reactionary and anti-democratic political right which resorted to a 'class struggle from above' (Gruner 1988; Jost 1992). Politically marginalised by the cooperation of bourgeois forces, Social-Democrats and trade unions could not prevent the working class from bearing most of the burden of economic setbacks during and after World War I.

The worldwide economic crisis of the 1930s brought mass unemployment also to Switzerland. Several strikes by angry workers were suppressed by federal troops, more than once ending in bloodshed. The left was denied what Catholics (in 1891) and farmers (in 1929) had achieved: recognition, political influence and participation in the Federal Council. Principles of proportional rule and participation were used to integrate cultural minorities, but not to resolve the problems of a growing socioeconomic cleavage.

On top of all that, the Socialist movement split. A communist faction claimed that bourgeois democracy was fake, an instrument of the capitalist class, and that the betterment of the working class could arrive only through political and economic revolution. In their view, only the politics of class struggle could overcome the market and profit systems and install the working class in power. Social-Democrats, on the other hand, insisted on proportional participation in all democratic institutions and trusted in limited reforms, even if the state remained in the hands of a bourgeois majority. They also aspired to a mixed economy, with a strong public sector and state intervention on behalf of social equality. This would not only improve the situation of workers, but also protect the Swiss economy from the deep, worldwide market crisis that then seemed inevitable. 
For almost four decades, until World War II, the workers' movements, politically discriminated against and internally divided, hesitated between radicalising the class struggle and cooperating in the hope of achieving integration. In the end, outside events gave the latter strategy the upper hand. Faced with the threats of fascism from Hitler's Nazi Germany, the SocialDemocrats gave up their opposition to militarise and supported the modernisation of the army. An important treaty between the employers' organisations and trade unions in the mechanical-engineering industry was signed in 1937: the so-called Labour Peace Convention (Friedensabkommen) accepted unions as representative organisations of the workers, proposed to resolve all conflicts by negotiation, and promised to end strikes and lockouts.

Economic and social inequalities-the predominant political issues in the twentieth century - thus finally began to be addressed through cooperation and integration. The Social-Democrats accordingly obtained their first seat in the Federal Council during World War II and were given adequate, that is, proportional, representation as of 1959.

The unifying experiences of the generation that defended Swiss independence and neutrality between 1939 and 1945 also had an effect. Ideological differences between the political left and right shrank. A large consensus amongst all political forces allowed the building up of a social security scheme, health care and insurance services, and a higher educational system, which reduced many areas of social and economic inequality. Economic growth led employers' and workers' organisations further towards cooperation and away from confrontation. Collective contracts, similar to the 1937 Labour Peace Convention, became the rule. Despite the fact that the labour force was less unionised than in other European countries, Swiss workers and employees obtained a fair share in the growth of prosperity (Linder 1983).

By the early 1970s, the highest degree of integration of different social classes in Switzerland had thus been reached. Employers and workers had gotten used to partnership, the left was integrated into the once purely bourgeois state. Political parties and economic organisations were able to reach consensus by compromise, power-sharing was effective. However, since then the social integration of Swiss society has somewhat declined. When economic growth turned into recession in 1974, the left learnt that proportional participation did not mean proportional influence. In 1984, a minority of the Social-Democrats even wanted to quit the Federal Council because political power-sharing was not shifting influence from the haves to the have-nots. Unions, which were willing to share the burden of recession 
by accepting pay cuts, were losing members and political influence. In the last decades, while achieving less from employers by way of contracts, unions have thus tried to promote social policy by way of legislation instead. This led to a shift from a liberal to a post-liberal welfare regime, in which social partnership plays a somewhat lesser role (Trampusch 2010).

In the last decades finally, globalisation and Europe-wide liberalisation have led to new conflicts between capital and labour, and between urban and rural areas as well. Despite polarisation between the right and the left, political power-sharing has persisted thus far, but the partnership between employers and unions has become more difficult to maintain, as we shall see in Chap. 5.

\subsection{Proportional Representation: The Universal Key to Power-Sharing}

In the preceding sections, we saw how linguistic and religious minorities became integrated, and then how conflicts arising from the social cleavages of modern industrial society were resolved. Conflict resolution in Switzerland relies very much on power-sharing rather than winner-take-all approaches. This section takes a closer look at the proportionality rule. It is a universal key to power-sharing in a double sense: it opens many doors to political participation for existing actors, and it can be used by new groups arising from new cleavages.

Let us first discuss the 'doors to power'. The proportional rule today is the key that unlocks the door to almost all political institutions. As can be seen from Table 2.3, the proportional rule is used for different criteria-or groups - in the same body. In the 'magic formula' of the seven-member Federal Council, for example, party affiliation is not the only criterion of proportionality. As already mentioned, the Federal Assembly follows the rule of linguistic proportionality, normally granting French- and Italianspeakers two or even three seats. Until 1999, a provision in the Constitution stated that there could not be more than one representative from the same canton. This criterion has been abandoned in favour of a new rule stipulating an appropriate representation of the various language regions. Gender balance has not (yet) become a formal rule, but in 2010 briefly led to a female majority in the Federal Council. Not only candidates for the Federal Council, but also high officials of the federal government must fulfil one or more criteria of proportionality to be eligible for a position. There is some criticism that this system means that the 'real' job requirements are all too often neglected (Box 2.8). 
Table 2.3 Use of the proportional rule: institutions and criteria

\begin{tabular}{llll}
\hline Institution & Language & Party & Gender \\
\hline Federal Council & $\mathrm{x}$ & $\mathrm{x}$ & $\mathrm{x}$ \\
National Council & $(\mathrm{x})$ & $\mathrm{x}$ & $(\mathrm{x})$ \\
Council of States & $\mathrm{x}$ & $\mathrm{x}$ & $(\mathrm{x})$ \\
Federal Supreme Court & $\mathrm{x}$ & $\mathrm{x}$ & $\mathrm{x}$ \\
Parliamentary committees & $\mathrm{x}$ & $\mathrm{x}$ & $(\mathrm{x})$ \\
Expert committees & $\mathrm{x}$ & $(\mathrm{x})$ & $\mathrm{x}$ \\
Nomination of high government officials & $\mathrm{x}$ & $(\mathrm{x})$ & $\mathrm{x}$ \\
\hline
\end{tabular}

Note: $\mathrm{x}=$ criteria normally used, $(\mathrm{x})=$ criteria sometimes important

\section{Box 2.8 Proportionality in Practice}

Proportionality does not mean quotas but is based on informal political claims, as the following illustrates:

When a French-speaking three-star general retires, the search for his replacement is practically limited to French-speakers. But what about a German-speaker who may be more qualified than the top Frenchspeaking candidate? The former is indeed discriminated against on the basis of his language affiliation. This is the price that the Swiss are willing to pay for their system of power-sharing. This price, however, should not be exaggerated. In the foregoing example, the highly qualified German-speaker simply has to wait until a three-star general of his own language retires. Sometimes, of course, bad luck may strike; no opening may occur when someone is the "ideal" age for a particular position. For example, a German-speaking Free Democrat of Catholic faith, regarded as a top candidate, may never make it to the Federal Council, because during his prime political years, his particular combination of attributes may never be demanded. (Steiner 1990, 109)

There is flexibility in the system in that over- or under-representation is temporarily allowed but must be compensated over time. Moreover, we cannot speak of formal 'group rights' because in most cases these are mere political claims which cannot be enforced by law (but are respected in most cases, though). The great majority of Swiss are opposed to rigid legal quota but like the idea that all groups of society should be fairly 
represented in public bodies. Proportionality, therefore, is a political rather than a legal practice.

Finally, this element of political culture applies even beyond politics and positions in government. It is practised in many cultural organisations and even in sport. This is true at least for the linguistic proportional rule. It would be unimaginable, for instance, that the executive committee of the Swiss Football Association would consist of German-speakers only.

\subsection{The Limits of Swiss Pluralism: New Challenges FOR INTEGRATION}

We may speak of true political pluralism if no societal group is discriminated against and if every group has a fair chance of exercising influence through political institutions. This requires a state that refrains from privileging or discriminating specific groups and whose laws enforce values common to all: human rights, basic rights and democracy, with all its implications of equality. Switzerland's multicultural society, thanks to the way it has been integrated, has achieved a remarkable standard of political pluralism. Peaceful conflict resolution through power-sharing is not only a pattern of political but also of social life.

There are limits, however, to peace and pluralism in Swiss society. In sharp contrast to the mutual respect among the larger groups, there has at times been heavy discrimination against smaller religious and ethnic groups. Children of gypsies, a group at odds with the rather rigid Swiss sense of order, have been taken away from their parents and raised in 'proper' homes. During World War II, Jewish refugees were sent back over the German border in order to avoid additional difficulties with the Nazi regime. For a long time, the rights of patients in psychiatric clinics and of sentenced and remanded prisoners did not meet the standards of other European countries (Kaufmann 1965, 245-62). During the Cold War and after, the federal intelligence service not only spied on extreme left-wing militants, but also on approximately 100,000 citizens who had done nothing more than support unorthodox political opinions or actions.

Another problem is gender. For a long time, Swiss women had to live in a society which only reluctantly began to abandon traditional malefemale roles. Until 1971, Switzerland was a comparatively incomplete democracy because it denied women the right to vote, let alone be given a political mandate. As we shall see in Chap. 3, federalism and direct democracy made introducing female suffrage a difficult task. When in 
1981 a constitutional amendment introduced legal, social and economic equality for women, the Swiss became aware that despite political pluralism, much discrimination persisted. Since then, legal discrimination against women - in the areas of family law and social security for instance-has been eliminated from all legislation. Today, the representation of women in the parliaments of the cantons and the federation is on par with that of neighbouring countries. In the last decade the proportion of gainfully employed women has increased more than in most highly industrialised countries.

On the other hand, women in Switzerland still mostly work in less qualified, worse paid jobs, are sometimes far from getting equal pay and are underrepresented in the higher ranks of management or universities. Whereas highly industrialised countries such as the US and Sweden have practised policies of affirmative action or equal pay for decades, Switzerland had to catch up in many fields of equal opportunity for women (EKF 1980-1999; Ballmer-Cao 2000; Ballmer-Cao and Trembley 2008; Senti 1995).

Finally, there is the question of foreign residents. Ever since the 1960s, the rapidly growing economy needed additional labour. Workers from Italy, Germany, France and Austria, and later from Spain, Portugal, former Yugoslavia and Turkey, found jobs in Switzerland. In 2015, the number of foreigners surpassed 2 million for the first time, and in 2019 stood at 2.1 million. That is $25 \%$ of the total population. A great part of them work in jobs that the Swiss avoid if they can. They pay taxes and contribute to all social security systems, but they generally have no political rights. ${ }^{9}$ Obtaining Swiss citizenship is difficult; a demand can only be placed after at least ten years of residence and the commune of residence decides, either through an expert committee or a citizen vote or both (e.g. Hainmueller and Hangartner 2013; Hainmueller et al. 2019).

While Swiss enterprises actively seek foreign workers, Switzerland has become an attractor to refugees and migrants from Third World countries (Table 2.4, Fig. 2.3). The social integration of this growing and heterogeneous foreign population sometimes challenges the capacities of political

\footnotetext{
${ }^{9}$ The exception are the French speaking cantons of Jura, Vaud, Neuchatel and Fribourgas well as some municipalities in Appenzell Outer-Rhodes and Grisons-which grant full political rights to foreign residents in communal affairs. See https://www.ekm.admin.ch/ $\mathrm{ekm} / \mathrm{de} / \mathrm{home} /$ staatsbuergerschaft-citoyennete/Citoy/buergerrechte/panorama.html [1.10.2019].
} 
Table 2.4 Foreign permanent resident population by citizenship, end of 2017

\begin{tabular}{lll}
\hline Citizenship/Origin & $1000 s$ & Share \\
\hline Italy & 317 & $15 \%$ \\
Ex-Yugoslavia $^{\text {a }}$ & 312 & $15 \%$ \\
Germany $^{\prime}$ & 305 & $14 \%$ \\
Portugal & 267 & $13 \%$ \\
France & 131 & $6 \%$ \\
Spain & 83 & $4 \%$ \\
Turkey & 68 & $3 \%$ \\
Austria & 42 & $2 \%$ \\
United Kingdom & 41 & $2 \%$ \\
Other European countries & 206 & $10 \%$ \\
Asia & 160 & $8 \%$ \\
Africa & 107 & $5 \%$ \\
Latin America and Caribbean & 54 & $3 \%$ \\
North America & 26 & $1 \%$ \\
Oceania & 4 & $0 \%$ \\
Stateless/not attributable/no & 2 & $0 \%$ \\
indication & & \\
Total & 2126 & $100 \%$ \\
\hline abosnia and Herzegovina, Croatia, & Kosovo, \\
Montenegro, North Macedonia, Serbia, and Slovenia \\
Source: BFs (2019)
\end{tabular}

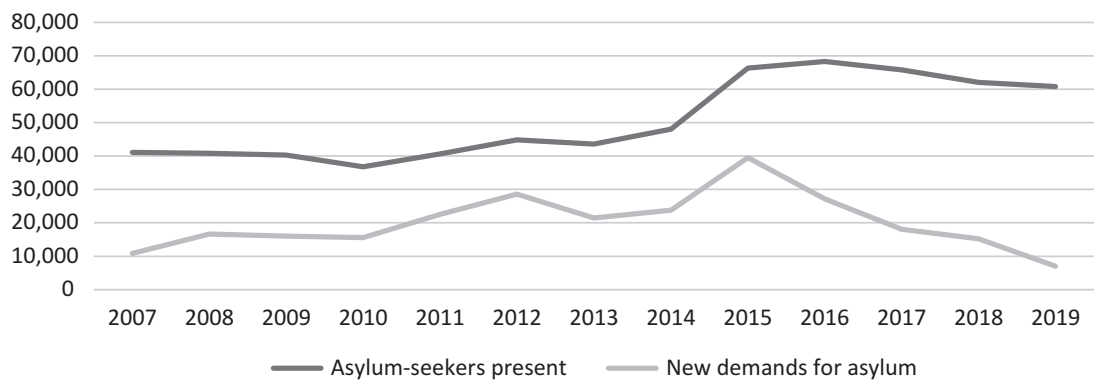

Fig. 2.3 Asylum seekers in Switzerland, 2007-2019. (Source: SEM (2019))

authorities, schools and some parts of society. Severe political tensions have arisen. Xenophobic parties developed and brought pressure on the political authorities to restrict immigration and avoid the 'over-alienation' (Überfremdung) of Swiss society. Foreign workers, asylum seekers and immigration remain highly controversial issues. 
To integrate foreigners in the same way as the native minority groups in the past will be much more difficult for Swiss society. Contrary to the past, it will also mean the integration of non-European cultural patterns, values, religious beliefs and mentalities, which is a new challenge. With over $25 \%$, Switzerland has the highest proportion of foreigners of all European countries except Luxembourg. In many jobs, Swiss workers are a minority, as are Swiss children in school classes where teachers have to handle up to ten languages spoken by immigrant pupils. For a long time, immigration policy followed the interest of industries which needed additional workforce with low qualifications but systematically underestimated the cost of social integration of new immigrant groups. In addition, competition between domestic and foreign workforce creates social tensions when jobs are cut. No wonder that immigration policy has become one of the most controversial issues.

\subsection{Conclusion}

Until the middle of the nineteenth century, Switzerland was neither a unified society nor a state. It was composed of several small societies with differing traditions, languages and religions that had become too limited to survive independently. In a bottom-up process, the cantonal peoples founded a united nation-state. It was based on a common Constitution, but not on a common language or religion. It was artificial, a product of historical circumstances, and could easily have failed. It lacked a coherent society. Surrounded by much more powerful and unified neighbours, the Swiss nation-state could still have been too small to survive. It could have been divided up and thus have fallen apart.

Yet, thanks to its political institutions and several felicitous circumstances, Switzerland became a nation willing to survive and found its own identity as a modern society. The case of Switzerland is thus an example of the successful integration of different cultures and of dealing with social inequalities. In this long-time process of societal integration, at least four political institutions or ideas played a key role:

- A non-ethnic concept of the nation-state: The most important factor behind Switzerland's success may be that it never had the choice of building a state based on one religion, one culture or one language. Forming a nation-state on that basis would not have resolved existing minority problems, or only at great social cost. Whether in 
attaching smaller units to a larger one or dividing up a larger unit into smaller ones, eliminating one minority problem merely creates others. In having no choice other than for all minorities to live together, Switzerland avoided becoming a mono-cultural nationstate. Instead, the non-ethnic concept of the state allowed the different peoples of the cantons to recognise each other as having equal rights, regardless of differences in religion, language or cultural heritage. Switzerland is a political nation, held together by the political will to live under the same Constitution.

- Federalism: Regional self- and shared rule were essential for the bottom-up process of nation-building. They allowed for a compromise between the opponents and the advocates of a strong central state. Up to these days, federalism provides utmost autonomy to the cantons and their different cultures whilst also securing national unity.

- Proportionality: Proportional representation was, step by step, introduced in all institutions of the central state. It encompasses parliament and its committees, the government, the courts, and expert committee as well as the federal administration. Proportional representation is applied not only for party affiliation but also for language, and belatedly also for gender, thus giving different societal groups adequate recognition and voice.

- Political power-sharing: Swiss democracy developed differently from the majoritarian or Westminster model of parliamentary government. Instead of competition between government and opposition, where 'the winner takes all' for at least four years, we find an oversized government coalition. Instead of majority or sometimes even plurality politics, decision-making in Swiss politics is characterised by negotiation, consensus-seeking and compromise. The development, characteristics and functioning of this 'power-sharing democracy' will be explained in-depth in Chap. 5. The essential point here is this: political power-sharing has facilitated peaceful conflict-resolution among culturally different groups. In contrast to competitive democracy, power-sharing has avoided the alienation of minorities arising from a perpetually winning majority.

Looking at the process of national integration, we note that the effect of political institutions is neither immediate nor perfect. It took time to overcome the deep conflicts between Catholics and Protestants, or between capital and labour. And while the religious and linguistic 
cleavages have cooled out, others like the economic cleavage might catch fire again if the market economy exacerbates risks and inequalities. Moreover, while integration was successful for the main linguistic and religious groups of civil society, some small minorities were discriminated against. Women also received their political rights much later than in other countries. And immigration is the new, big challenge for integration. Immigration has become a controversial and important political issue precisely because it has created problems of integration that cannot be solved by the political mechanisms described above.

Finally, there are external factors that helped create and maintain national unity. Pressure from the outside was one of the basic motivations for the creation of the federation in 1848: the Swiss cantons, surrounded by much bigger nation-states, wanted to keep their autonomy and independence. Pressure from the outside has been relevant ever since, but never materialised in armed intervention. Armed neutrality has allowed Switzerland to stay out of the belligerent conflicts between Germany and France in 1871 and both World Wars. With the end of the Cold War in 1989 and the Eastward expansion of North Atlantic Treaty Organisation (NATO), armed neutrality lost much of its practical importance in foreign policy, yet it still is a commonly shared value of all Swiss. Most citizens feel that the government of a small state should not expose itself in international conflicts.

Yet when it comes to current challenges, the Swiss seem less united. On the question of European integration, they are divided between (an albeit dwindling number of) protagonists of membership and those who prefer bilateral treaties with the EU. Globalisation has led to new social tensions between winners and losers, and heavy immigration is sometimes followed by problems of integration. In times of pressure from the outside, as during the financial and economic crisis of 2008/2009 when the Swiss government was forced to renounce on the traditional 'banking secrecy' and to adapt OECD standards for cooperation in fiscal affairs, the Swiss are still undecided on their future identity.

This is different from the past, when pressure from the outside-for example Mussolini's irredentism towards Ticino-was a constant factor that brought the Swiss together in the idea of protecting and maintaining their national unity and independence. In the end, however, this past is still present. To this day, the Swiss are constitutional patriots and feel as a 'nation of political will', and as 'being different from others'. While lacking a common language or religion, and despite conflict, the Swiss are 
proud of what they all share as citizens: their political architecture and the civic rights that come with it. The three most important elements of that architecture-federalism, direct democracy and power-sharing-will be described in the following chapters.

\section{REFERENCES}

Altermatt, Urs. 1991. Katholizismus und Moderne. Zürich: Benziger.

Andrey, Georges. 1983. Auf der Suche nach dem neuen Staat. In Geschichte der Schweiz und der Schweizer, ed. Jean-Claude Favez, vol. II, 527-638. Basel/ Frankfurt am Main: Helbing und Lichtenhahn.

Ballmer-Cao, Thanh-Huyen. 2000. Changement social et rapport entre hommes et femmes. Lausanne: Editions Payot.

Ballmer-Cao, Thanh-Huyen, and Manon Trembley, eds. 2008. Modes de scrutin, partis politiques et élection des femmes. Swiss Political Science Review 14 (4): 609-630.

BAR - Schweizerisches Bundesarchiv [Swiss Federal Archives]. 2011. Der Bund, das Parlament und seine Stühle. Geschichte aktuell. www.bar.admin.ch. Accessed 1 October 2019.

BFS - Bundesamt für Statistik [Federal Statistical Office]. 2019. Various data. www.bfs.admin.ch. Accessed 31 December 2019.

BK - Bundeskanzlei [State Chancellery]. 2019. Various Data. www.bk.admin.ch. Accessed 1 October 2019.

du Bois, Pierre. 1999. Alémaniques et Romands entre unité et discorde: histoire et actualité. Lausanne: Favre.

BR - Bundesrat [Federal Council]. 2016. Bericht über die vom Bundesrat im Rabmen der Gesamterneuerungswablen für die Amtsperiode 2016-2019 gewählten ausserparlamentarischen Gremien. Bern, 4 May 2016. https://www. admin.ch/opc/de/federal-gazette/2016/4183.pdf. Accessed l October 2019.

BV - Bundesverfassung der Schweizerischen Eidgenossenschaft [Federal Constitution of the Swiss Confederation]. 1999. Version of 18 April 1999, Status as of 23 September 2018. Unofficial English version. www.admin.ch/ opc/en/classified-compilation/19995395/index.html. Accessed l October 2019.

Church, Clive H. 2004. The Politics and Government of Switzerland. Basingstoke/ New York: Palgrave Macmillan.

- 2016. Political Change in Switzerland: From Stability to Uncertainty. London/New York: Routledge.

CIA World Factbook. 2019. www.cia.gov/library/publications/the-worldfactbook. Accessed l October 2019. 
Dardanelli, Paolo, and Nenad Stojanović. 2011. The Acid Test? Competing Theses on the Nationality - Democracy Nexus and the Case of Switzerland. Nations and Nationalism 17 (2): 357-376.

Delegate for Plurilinguism. 2019. Förderung der Mehrsprachigkeit innerbalb der Bundesverwaltung. Bern, 20 December 2019. https://www.plurilingua. admin.ch/plurilingua/de/home/debatten-aktualitaet/nsb-news_list.msgid-77659.html. Accessed 20 December 2019.

Demont-Heinrich, Christof. 2005. Language and National Identity in the Era of Globalization: The Case of English in Switzerland. Journal of Communication Inquiry 29 (1): 66-84.

Deutsch, Karl. 1967. The Nerves of Government: Models of Political Communication and Control. New York: Free Press.

- 1976. Die Schweiz als paradigmatischer Fall politischer Integration. Bern: Haupt.

EKF - Eidgenössische Kommission für Frauenfragen [Federal Commission for Women's Issues]. 1980-1999. Die Stellung der Frau in der Schweiz/Gleiche Rechte für Mann und Frau/Die politische Repräsentation der Franen in der Schweiz/Viel erreicht - wenig verändert?/Frawen Macht Geschichte. Bern: Eidgenössische Kommission für Frauenfragen. https://www.ekf.admin.ch/ ekf/de/home/dokumentation/studien-und-empfehlungen.html. Accessed 1 October 2019.

Ernst, Andreas, Albert Tanner, and Matthias Weishaupt, eds. 1998. Revolution und Innovation - Die konfliktreiche Entstehung des schweizerischen Bundesstaats von 1948. Zürich: Chronos.

Eugster, Beatrice, and Oliver Strijbis. 2011. The Swiss: A Political Nation? Swiss Political Science Review 17 (4): 394-416.

Farago, Peter. 1987. Verbünde als Träger öffentlicher Politik. Grüsch: Rüegger.

Gabriel, Jürg Martin. 1995. Die Nentralität auf dem Prüfstand. St. Gallen: Institut für Politikwissenschaft.

Gabriel, Jürg Martin, and Thomas Fischer, eds. 2003. Swiss Foreign policy, 1945-2002. Basingstoke: Palgrave.

Giudici, Anja, and Nenad Stojanovic. 2016. Die Zusammensetzung des Schweizerischen Bundesrates nach Partei, Region, Sprache und Religion, 1848-2015. Swiss Political Science Review 22 (2): 288-307.

Goetschel, Laurent. 2007. Foreign Policy. In Handbook of Swiss Politics, ed. Ulrich Klöti et al., 571-591. Zürich: Neue Zürcher Zeitung Publishing.

Gruner, Erich. 1964. 100 Jahre Wirtschaftspolitik: Etappen des Staatsinterventionismus in der Schweiz. Schweizerische Zeitschrift für Volkswirtschaft und Statistik 100: 35-70.

-1988. Arbeiterschaft und Wirtschaft in der Schweiz 1880-1914. Zürich: Chronos. 
Hainmueller, Jens, and Dominik Hangartner. 2013. Who Gets a Swiss Passport? A Natural Experiment in Immigrant Discrimination. American Political Science Review 107 (1): 159-187.

Hainmueller, Jens, Dominik Hangartner, and Dalston Ward. 2019. The Effect of Citizenship on the Long-Term Earnings of Marginalized Immigrants: Quasiexperimental Evidence from Switzerland. Science Advances 2019 (5): 1-8.

Huston, James H. 1991. The Sister Republics. Washington: Library of Congress.

Im Hof, Ulrich. 1991. Mythos Schweiz. Identität-Nation-Geschichte. Zürich: Verlag Neue Zürcher Zeitung.

Jost, Hans Ulrich. 1986. Menace et repliement (1914-1945). In Nouvelle histoire de la Suisse et des Suisses, ed. Jean-Claude Favez, vol. III, 91-178. Lausanne: Payot.

- 1992. Die reaktionäre Avantgarde: Die Geburt der neuen Rechten in der Schweiz um 1900. Zürich: Chronos.

Kästli, Tobias. 1998. Die Schweiz - eine Republik in Europa. Zürich: Verlag Neue Zürcher Zeitung.

Kaufmann, Otto K. 1965. Frauen, Italiener, Jesuiten, Juden und Anstaltsversorgte. Vorfragen eines Beitritts der Schweiz zur Europäischen Menschenrechtskonvention. St. Galler Festgabe zum Schweizerischen Juristentag 1965. Bern: Stämpfli.

Kley, Andreas. 2011. Bundesverfassung (BV). Historisches Lexikon der Schweiz. https://hls-dhs-dss.ch/de/articles/009811/2011-05-03/. Accessed 1 October 2019.

Kölz, Alfred. 1992. Nenere Schweizerische Verfassungsgeschichte. Bern: Stämpfli.

Kreis, Georg, Jean-Claude Favez, and Urs Altermatt. 1992. Geschichte der schweizerischen Aussenpolitik 1848-1991. In Neues Handbuch der schweizerischen Aussenpolitik, ed. Alois Riklin, 27-78. Bern: Haupt.

Kriesi, Hanspeter. 1980. Entscheidungsstrukturen und Entscheidungsprozesse in der Schweizer Politik. Frankfurt/New York: Campus Verlag.

Kux, Stephan, ed. 1994. Zukunft Neutralität? Bern: Haupt.

Linder, Wolf. 1983. Entwicklung, Strukturen und Funktionen des Wirtschaftsund Sozialstaats in der Schweiz. In Handbuch Politisches System der Schweiz, ed. Alois Riklin, vol. I, 255-382. Bern/Stuttgart: Haupt.

Mach, André. 2007. Interest Groups. In Handbook of Swiss Politics, ed. Ulrich Klöti et al., 359-380. Zürich: Neue Zürcher Zeitung Publishing.

Masnata, François, and Claire Rubattel. 1991. Le pouvoir Suisse, 1291-1991: Séduction démocratique et répression suave. Lausanne: Editions de l'aire.

Mazzoleni, Oscar, and Paolo Dardanelli, eds. 2019. Svizzera-UE: un rapporto irrisolto. Locarno: Armando Dadò.

McRae, Kenneth D. 1964. Switzerland: Example of Cultural Coexistence. Toronto: The Canadian Institute of International Affairs.

Meuwly, Olivier. 2018. Une histoire politique de la démocratie directe en Suisse. Neuchâtel: Editions Alphil. 
Niederer, Arnold. 1965. Gemeinwerk im Wallis: bänerliche Gemeinschaftsarbeit in Vergangenheit und Gegenwart. Basel: Krebs.

Rappard, William E. 1912. Le facteur économique dans l'avénement de la démocratie moderne en Suisse. Genéve: Georg.

Remak, Joachim. 1993. A Very Civil War: The Swiss Sonderbund War of 1847. Boulder, CO: Westview.

Riklin, Alois. 1991. Funktionen der schweizerischen Neutralität. St. Gallen: Institut für Politikwissenschaft.

- 2006. Neutralität am Ende? 500 Jahre Neutralität der Schweiz. Zeitschrift für Schweizerisches Recht 125 (1): 583-598.

Roca, René. 2012. Sonderbund. Historisches Lexikon der Schweiz. https://hls-dhsdss.ch/de/articles/017241/2012-12-20. Accessed l October 2019.

Ruckstuhl, Brigitte. 1991. Die Schweiz - ein Land der Bauern und Hirten. In Auf wen schoss Wilhelm Tell? ed. Silvia Ferrari et al., 135-170. Zurich: Rotpunktverlag.

Ruffieux, Roland. 1983. La Suisse des radicaux (1848-1914). In Nouvelle histoire de la Suisse et des Suisses, ed. Jean-Claude Favez, vol. II, 7-90. Lausanne: Payot.

Schmid, Carol L. 2001. The Politics of Language: Conflict, Identity, and Cultural Pluralism in Comparative Perspective. New York: Oxford University Press.

SEM - Staatssekretariat für Migration [State Secretariat for Migration]. 2019. Asylstatistik. https://www.sem.admin.ch/sem/de/home/publiservice/statistik/asylstatistik.html. Accessed 1 September 2019.

Senti, Martin. 1995. Geschlecht als politischer Konflikt. Bern: Haupt.

Soland, Rolf. 1980. Joachim Leonz Eder und die Regeneration im Thurgan 1830-1831: Ein Kapitel aus der thurganischen Verfassungsgeschichte. Weinfelden: Mühlemann.

SRG. 2019. Geschüftsbericht 2018. Online. www.srgssr.ch/gb2018. Accessed 1 October 2019.

Steiner, Jürg. 1990. Power-sharing: Another Swiss 'export-product'? In Conflict and Peacemaking in Multiethnic Societies, ed. Joseph V. Montville, 107-114. Massachusetts/Toronto: Lexington Books.

Stepan, Alfred. 1999. Federalism and Democracy: Beyond the U.S. Model. Journal of Democracy 10: 19-34.

Swissvotes. 2019. Database on Swiss Popular Votes. Ed. Année Politique Suisse, University of Bern. Online. www.swissvotes.ch. Accessed l October 2019.

Trampusch, Christine. 2010. The Welfare State and Trade Unions in Switzerland. A Historical Reconstruction of the Shift from a Liberal to a Post-Liberal Welfare Regime. Journal of European Social Policy 20 (1): 58-73.

Vatter, Adrian. 2018a. Das politische System der Schweiz. 3rd ed. BadenBaden: Nomos.

- 2018b. Swiss Federalism: The Transformation of a Federal Model. London: Routledge. 
Watts, Richard J. 1991. Linguistic Minorities and Language Conflict in Europe: Learning from the Swiss Experience. In Language Policy for the EC, ed. Florian Coulmas, 75-102. Berlin: Mouton de Gruyter.

Werlen, Iwar. 2008. Englisch als Fremdsprache bei Erwachsenen in der Schweiz. In Sprachkontakt und Mehrsprachigkeit, ed. Sandro Moraldo, 193-214. Heidelberg: Winter.

Windisch, Uli. 1992. Les relations quotidiennes entre Romands et Alémaniques. Lausanne: Editions Payot.

Zimmer, Oliver. 2003. A Contested Nation: History, Memory and Nationalism in Switzerland, 1761-1891. Cambridge: Cambridge University Press.

Open Access This chapter is licensed under the terms of the Creative Commons Attribution 4.0 International Licence (http://creativecommons.org/licenses/ by $/ 4.0 /$ ), which permits use, sharing, adaptation, distribution and reproduction in any medium or format, as long as you give appropriate credit to the original author(s) and the source, provide a link to the Creative Commons licence and indicate if changes were made.

The images or other third party material in this chapter are included in the chapter's Creative Commons licence, unless indicated otherwise in a credit line to the material. If material is not included in the chapter's Creative Commons licence and your intended use is not permitted by statutory regulation or exceeds the permitted use, you will need to obtain permission directly from the copyright holder.

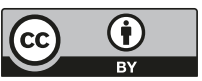

